\title{
Review
}

\section{Molecular and Cellular Mechanisms Influenced by Postbiotics}

\author{
Rafał Jastrząb (D), Damian Graczyk (D) and Pawel Siedlecki *(D) \\ Institute of Biochemistry and Biophysics, Polish Academy of Sciences, 02-106 Warsaw, Poland; \\ jastrzab@ibb.waw.pl (R.J.); dgraczyk@ibb.waw.pl (D.G.) \\ * Correspondence: pawel@ibb.waw.pl
}

Citation: Jastrząb, R.; Graczyk, D.; Siedlecki, P. Molecular and Cellular Mechanisms Influenced by Postbiotics. Int. J. Mol. Sci. 2021, 22 13475. https://doi.org/10.3390/ ijms222413475

Academic Editor: Maria Santagati

Received: 11 October 2021

Accepted: 7 December 2021

Published: 15 December 2021

Publisher's Note: MDPI stays neutral with regard to jurisdictional claims in published maps and institutional affiliations.

Copyright: (c) 2021 by the authors. Licensee MDPI, Basel, Switzerland. This article is an open access article distributed under the terms and conditions of the Creative Commons Attribution (CC BY) license (https:// creativecommons.org/licenses/by/ $4.0 /)$.

\begin{abstract}
In recent years, commensal bacteria colonizing the human body have been recognized as important determinants of health and multiple pathologic conditions. Among the most extensively studied commensal bacteria are the gut microbiota, which perform a plethora of functions, including the synthesis of bioactive products, metabolism of dietary compounds, and immunomodulation, both through attenuation and immunostimulation. An imbalance in the microbiota population, i.e., dysbiosis, has been linked to many human pathologies, including various cancer types and neurodegenerative diseases. Targeting gut microbiota and microbiome-host interactions resulting from probiotics, prebiotics, and postbiotics is a growing opportunity for the effective treatment of various diseases. As more research is being conducted, the microbiome field is shifting from simple descriptive analysis of commensal compositions to more molecular, cellular, and functional studies. Insight into these mechanisms is of paramount importance for understanding and modulating the effects that microbiota, probiotics, and their derivatives exert on host health.
\end{abstract}

Keywords: postbiotics; probiotics; mechanism of action

\section{Introduction}

When dealing with the human microbiome and its influence on human health, we are considering about 100 times more bacterial genes than present in the human genome [1]. It is not only the products of these genes that can interact with the host. Components of bacterial cells, such as lipopolysaccharides (LPS) [2], or metabolites, such as short-chain fatty acids (SCFA), efficiently target host metabolic and immune systems [3,4]. The host is also capable of influencing the composition of the microbiome, e.g., by regulating the synthesis of specific proteins [5] or by expressing specific receptor variations [6]. Such cross-talk interactions reveal the dynamic states contributing to homeostasis between the bacterial community and the host. An increasing amount of research indicates that it is possible to modulate this state by the administration of probiotics or bacterial byproducts.

Several strategies have been suggested to regulate gut microbiome dysbiosis; among them are antibiotics, prebiotics, and probiotics [7]. Probiotics are live microorganisms that confer health benefits on the host [8]. Their impact on host health is now commonly recognized, with evidence of immunomodulatory [9,10], hypocholesterolemic [11], antiobesogenic [12], anti-hypertensive [13], anti-proliferative [14], anti-neurodegenerative [15,16], and antioxidant effects [17]. Probiotic administration has its limitations, mainly due to the potential risk of infection/bacteremia [18] and the possibility of transmitting antibiotic resistance genes (extensively discussed in $[19,20]$ ). Non-viable probiotics, called postbiotics, may present a safer alternative with similar physiological effects [21,22]. The term "postbiotics" is relatively new and refers to non-living microorganisms and their cell components, with or without metabolism products; in this sense, postbiotics distinguishes itself from the pro and synbiotics definitions [23]. In the literature, a few synonymous terms can be found, such as paraprobiotics, ghost probiotics, non-viable probiotics, or inactivated/non-viable microbial cells [24-26]. Postbiotic administration is a novel, promising strategy for a growing number of diseases, especially for those that affect the immune system $[27,28]$. Here, 
we review the influence of postbiotic elements (Table 1) on cellular signaling pathways, summarize the strategies of postbiotic usage, and discuss their current pitfalls. We show that from a technological point of view, postbiotics may be an interesting source of raw materials/active pharmaceutical ingredients (APIs) for drug discovery and production processes. We specifically focus on interactions of specific postbiotic elements (and their combination) with molecular targets, which we believe is the route to a safer and more controllable alternative to live probiotic administration.

Table 1. Postbiotic elements present in supernatants or in heat-killed/inactivated bacteria.

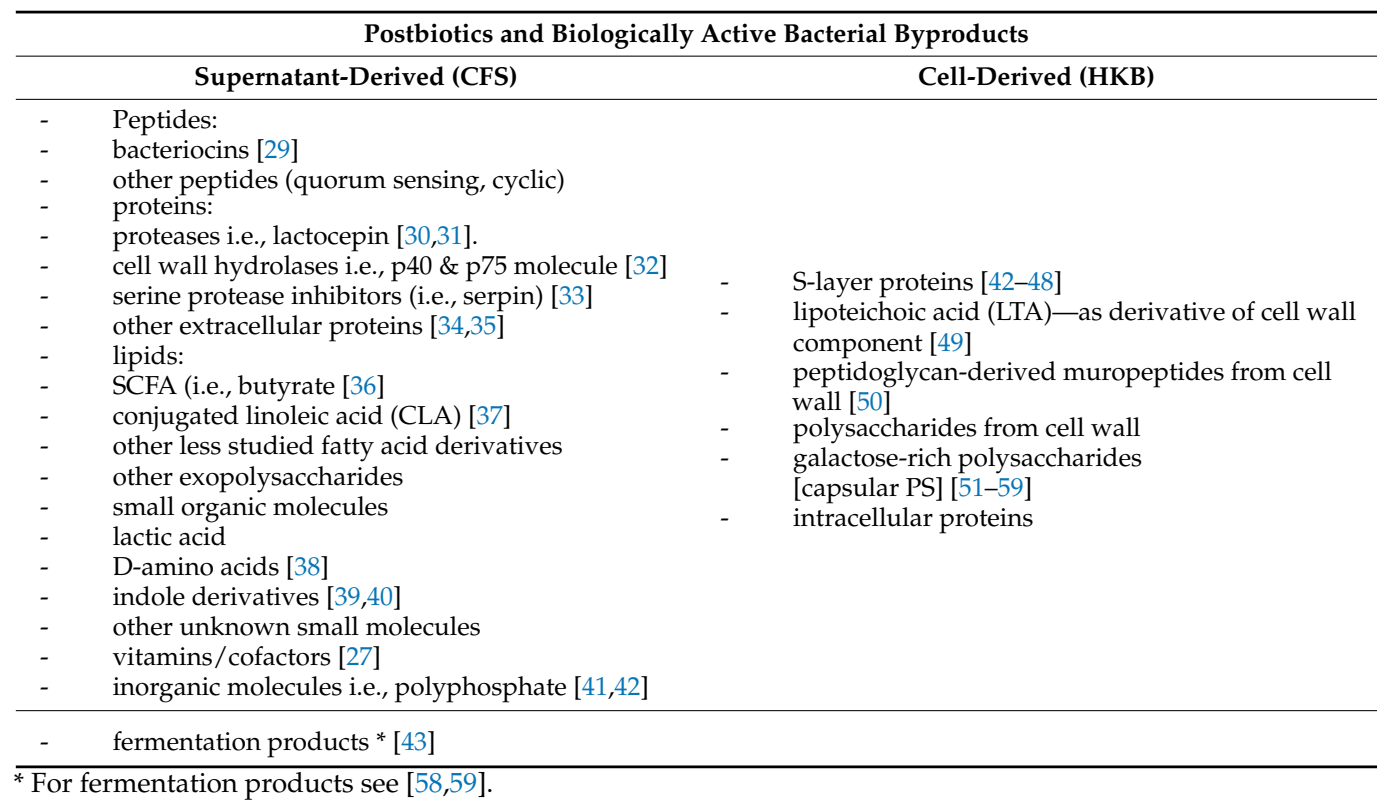

This review provides granular information about the origin and routes of interaction of postbiotics with host receptors. Emphasis is placed on the relationship between structure and activity, and how it can explain some of the contradictory results obtained by the field. We also discuss the interplay between cellular pathways, which is crucial for shaping the final immunological response to postbiotics. We show the impact of experimental design on the obtained results and finally, we hypothesise how to broaden the application of postbiotics-derived factors for use in human health care.

\section{The Impact of Postbiotics on Immunomodulatory Pathways}

One of the best-described pro-health properties of postbiotics is their immunomodulatory potential. In a recent study performed on patients with atopic dermatitis, postbiotic administration (of heat-killed Lactobacillus rhamnosus IDCC 3201) led to the remission of symptoms and reduced overall systemic inflammation [60]. In such studies, however, the observed effects are a result of multi-ingredient postbiotic fractions in which the compounds are not strictly defined. A potential immunomodulatory effect could originate from a peptide/protein, cell wall components such as lipoteichoic acid (LTA), small molecules (i.e., short-chain fatty acids (SCFA)), or a combination of these elements [61,62]. These studies often do not clarify which fraction is responsible for the observed health properties. This frequently leads to complex cellular responses, which often are contradictory depending on the origin and composition of the tested material, as well as the experimental settings used. Below, we summarize the impact of postbiotics on the typical pathways involved in immune responses, and where possible, we describe the molecular mechanisms.

\subsection{NF- $\kappa B$ and MAPK Pathways}

Inflammation is one of the reactions of organisms to infection or tissue injury. However, prolonged inflammation is a source of harmful effects observed in many inflammatory dis- 
eases, such as inflammatory bowel disease (IBD), arthritis, gastritis, asthma, or atherosclerosis. The common characteristic feature of these diseases is dysregulation of the nuclear factor kappa-light-chain-enhancer of activated B cell (NF- $\mathrm{kB}$ ) and/or mitogen-activated kinase (MAPK) pathways [63-66].

The NF- $\mathrm{KB}$ complex and MAPK are two crucial pathways involved in inflammatory responses and in the regulation of the cell cycle. Both pathways can cooperate through shared common receptors and downstream signaling proteins $[67,68]$. A wide spectrum of compounds contained in postbiotics can directly or indirectly target these pathways, although this does not always result in a similar response. This is a consequence of bacterial strain specificity in the stimulation or attenuation of the inflammatory response, which is a common theme seen in the literature. Nevertheless, the administration of postbiotics seems to be an attractive and promising potential therapeutic intervention to alleviate excessive and/or prolonged inflammatory responses. Many probiotics have shown efficacy in alleviating the symptoms of IBD and other inflammatory gastrointestinal diseases. NF- $\mathrm{KB}$ and/or MAPK pathways have been proposed to be the key molecular targets of compounds contained in these probiotics [69-72].

\subsubsection{Molecular Mechanism of NF-kB Signalling}

The NF- $\kappa B$ pathway is one of the best-studied intracellular circuits governing inflammatory responses. The transcription factor NF- $\mathrm{kB}$ regulates multiple aspects of innate and adaptive immune functions [73]. There are five mammalian members of the NF- $k B$

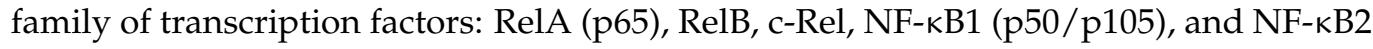
(p52/p100) [74]. NF-kB DNA binding activity consists of many possible homo and heterodimers, although p50/RelA heterodimers are most commonly observed [75]. Under normal cellular conditions, NF- $\mathrm{kB}$ binds to and is negatively regulated by an inhibitor of kappa B (IкB) in the cytoplasm. Following an inflammatory stimulus, IKB is phosphorylated by the I $\mathrm{KB}$ kinase (IKK) complex and undergoes proteasomal degradation. This allows NF-KB to translocate to the nucleus, where it regulates the transcription of a wide variety of target genes-including chemokines, interleukins, adhesion molecules (i.e., ICAM and VCAM), and antiapoptotic factors such as Bcl-2 and Bcl-xL-and also changes in immune cell activity, for example, the differentiation of T-cells, the maturation of dendritic cells (DCs), or polarization of macrophages. The final outcome of activation may vary depending on the type of activated cell as well as the signal transduction pathway [74]. Importantly, postbiotic elements are recognized directly or indirectly by multiple receptor families; signals originating from these receptors may lead to phosphorylation and subsequent ubiquitin-dependent degradation of IKB.

\subsubsection{MAPK Signalling Pathway}

MAPKs belong to the large, evolutionarily conserved family of serine/threonine kinases. They consist of three main subfamilies: c-Jun N-terminal kinases (JNKs), extracellular signal-regulated kinases (ERKs), and p38 MAP kinases [76]. The ERK pathway responds mainly to mitogens and growth factors, controlling cell cycle and differentiation [77]. The other two pathways have a wider influence on cellular response. Besides cell cycle and differentiation, JNK and p38 proteins are also engaged in apoptosis, cytokine production, regulation of proliferation, and inflammatory responses [78-80].

MAPK pathway signal transduction is based on phosphorylation cascades. The first kinases, MAP kinase kinase kinase (MAPKKK), are activated by a large group of "secondmessenger" proteins, such as RAS/RAC proteins, or receptors such as tyrosine kinases (RTKs), G-protein-coupled receptors (GPCRs), integrins, small GTPases Ras and Rap, TNFRs, or pattern recognition receptors (PRRs). MAPKKKs phosphorylate and activate MAPKK kinases (e.g., MKK4 and MKK7), which further phosphorylate MAPK effector kinases (ERK, JNK, and p38). Phosphorylated MAPKs execute cellular responses via multiple protein effectors, such as other kinases or transcription factors [80-82]. 


\subsubsection{Postbiotics' Influence on NF- $\mathrm{kB}$ and MAPK Pathways}

The effects that postbiotics exert on inflammatory pathways have been studied by numerous groups. Reports have highlighted changes in the transcription of pro-inflammatory genes, modified pro-inflammatory protein expression levels, or changes in overall cell response to stimuli [83-86]. However, the observed results differ; the reported pro- or anti-inflammatory effects depend on the postbiotic origin, bacterial species or strains [87], or even between cell-free supernatants (CFS) and heat-killed bacteria (HKB) [88]. Both anti-inflammatory and immunostimulatory effects have been demonstrated, suggesting that a heterogeneous structure and composition of different postbiotic media or additional factors influence the final results.

Postbiotics, both from CFS and HKB, mediate anti-inflammatory functions mostly via the attenuation of NF- $\mathrm{KB}$ activity [89-92]. The mechanisms of this attenuation frequently involve the inhibition of NF- $\mathrm{kB}$ nuclear translocation via the inhibition of IкB phosphorylation and the prevention of its proteasomal degradation $[32,93,94]$. Furthermore, the CFS of L. rhamnosus CNCM I-4036 was reported to enhance the expression of an IкB subunit, NFKBIA, and thus tighten NF- $\mathrm{kB}$ sequestering in the cytoplasm [95].

Both NF- $\mathrm{KB}$ and MAPK pathways are triggered by a common group of PRRs, and thus, the downstream events may be affected simultaneously, leading to the attenuated inflammatory response through decreased NF- $\mathrm{kB}$ activity and MAPK phosphorylation. This has been observed for HKB and CSF and also isolated postbiotic factors such as $8.7 \mathrm{kDa}$ proteins from L. plantarum 10hk2 CFS [96], L. rhamnosus LGG-derived DNA [97], HKB of Weissella cibaria JW15 [98], and CFS of L. salivarius MG4265 [99]. In all of these studies, the decreased NF- $\kappa B$ activity (inhibition of $\mathrm{I} \kappa \mathrm{B} \alpha$ degradation and/or translocation) and $\mathrm{p} 38$ phosphorylation were observed.

The immunostimulatory potential directly connected to NF- $\mathrm{KB} / \mathrm{MAPK}$ activation has also been reported in the literature. For example, multiple HKB of Lactobacilli strains were able to increase the nuclear translocation of NF-KB subunit p65 $[100,101]$ and to stimulate inflammatory responses. In the case of MAPK, activation by secreted peptides $[102,103]$ and HKB $[47,104]$ has been reported, resulting in the increased production of heat-shock proteins (especially HSP25 i HSP72) and beta-defensin 2 (hBD-2). These may positively influence intestinal barrier integrity and improve the protection of the host against infection $[105,106]$. Additionally, CFS from L. reuteri induced apoptosis via MAPK activation [107].

Finally, some reports show a dual mode of action: the activation of both NF- $\mathrm{kB}$ and p38 MAPK signaling. This has been observed with HKB of L. plantarum KCTC 13314BP [108], exopolysaccharides (EPS) [109], and S-layer proteins isolated from L. acidophilus NCFM [110]. Interestingly, S-layer proteins isolated from L. acidophilus NCFM showed different activity depending on the cell type and testing conditions; they stimulated the MAPK pathway in the human adenocarcinoma cell line, HCT116, whereas in the murine macrophage cell line, RAW264, they attenuated NF-kB and MAPK pathway activities $[110,111]$.

The vast majority of cited studies have focused on the effects of postbiotics on NF- $\mathrm{kB}$ translocation to the nucleus, proteasomal degradation of NFKBIA, or phosphorylation of MAPK kinases (Figure 1). However, the exact influence of postbiotics on downstream signaling pathways needs to be further explored, as their influence is not always obvious and consistent. Moreover, structure-activity assays may provide much better insight into the molecular basis of the described interactions and may help to design more targeted approaches using postbiotic sources. 


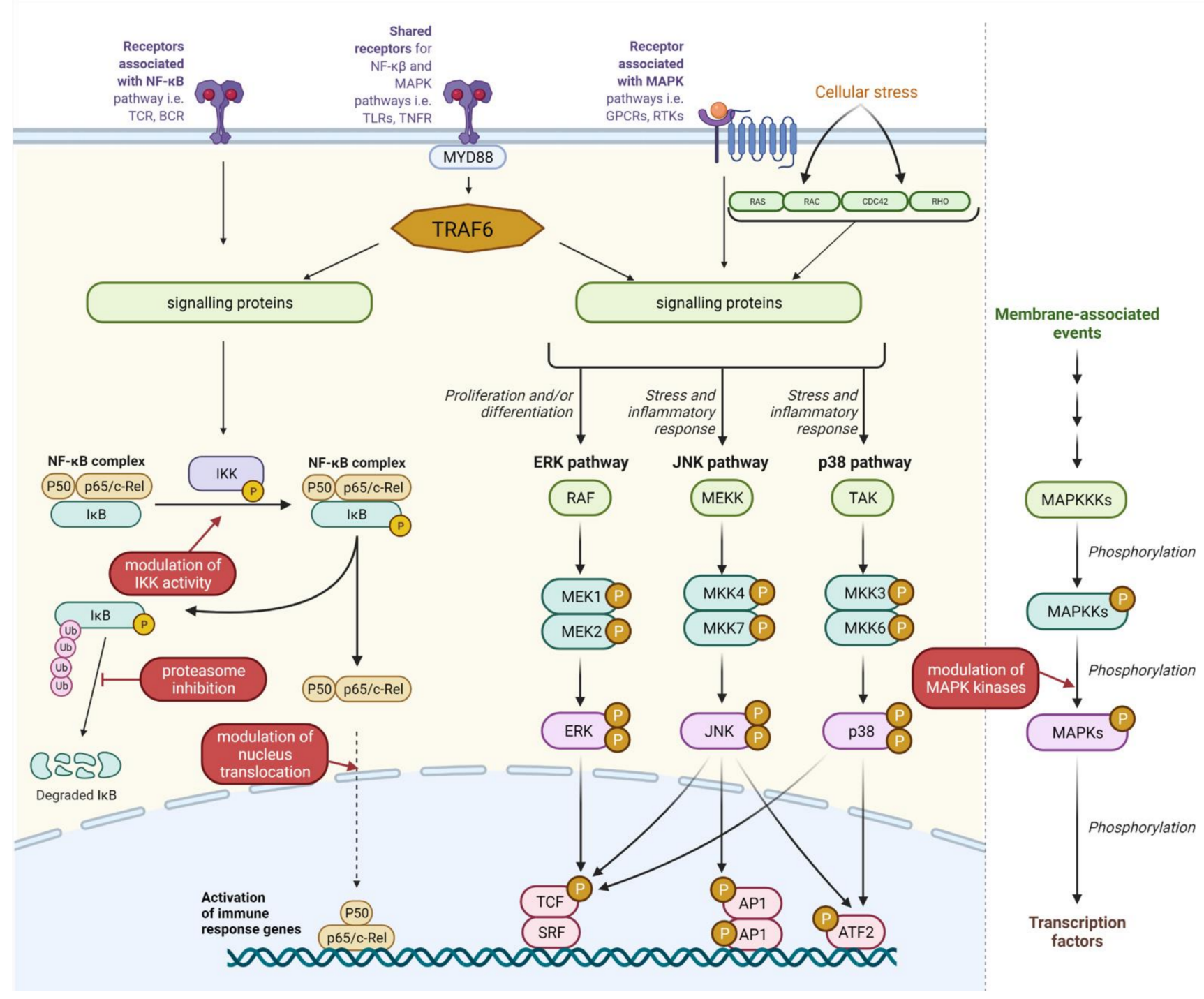

Figure 1. NF- $\mathrm{KB}$ and MAPK pathways and their modulation by postbiotic molecules. TCR-T-cell receptors, BCR-B-cell receptors, TLRs—-toll-like receptors, TNFR-TNF $\alpha$ receptors superfamily, IKK-IKK kinase complex, GPCRs—G protein coupled receptors, RTKs-receptor tyrosine kinase, MyD88-myeloid differentiation factor 88, TRAF6-TNF receptor associated factor 6, Ras-Ras GTPase, Rac—Rac GTPases, CDC42-Cell division control protein 42, Rho-Rho GTPases. MAPKKKs -mitogen activated kinase kinase kinases which including: RAF, MEKK and TAK kinases, MAPKKs-mitogen activated kinase kinases including: MEK1, MEK2, MKK4, MKK7, MKK3, MKK6. MAPKs—mitogen activated kinases including: ERK-Extracellular signal-regulated kinase, JNK—c-Jun N-terminal kinases, p38—p38 mitogen-activated protein kinases (p38s), AP1—activator protein 1, ATF2—cyclic AMP-dependent transcription factor, TCF-LEF/TCF family of nuclear factors, SRF- serum response factor. Created with BioRender.com, accessed on 10 October 2021.

\subsection{Other Mechanisms and Molecular Pathways}

The intestinal barrier is exposed to multiple harmful factors, which can negatively affect cell survival and disrupt the barrier's integrity. The influence of probiotic components and metabolites on the regulation of intestinal epithelial barriers has been recently discussed in detail elsewhere [112]. Nevertheless, from a molecular point of view, PI3K/AKT is frequently mentioned as a potential target pathway for postbiotic factors, controlling intestinal barrier functionality. PI3K/AKT modulates cell survival, apoptosis, and intestinal integrity, e.g., mucin production [113]. This pathway may cooperate with NF- $\mathrm{kB}$ and MAPK cascades modulating immune responses toward probiotic/postbiotic compounds [114-117]. The PI3K/AKT pathway is also interconnected with the AMP-activated 
kinase (AMPK) pathway, a metabolic pathway, which is another cellular effector of probiotics/postbiotics [118-120].

The activation of protein kinase $\mathrm{B}(\mathrm{PKB} / \mathrm{Akt}$ ) by postbiotics is also prevalent in the literature. PKB plays a role in various cellular responses generally conferring health benefits, such as attenuating inflammatory responses to isolated LGG peptides $\mathrm{p} 40$ and p75 [121-123], increasing mucin production (or muc2 gene expression) in response to butyrate and purified protein HM0539 from LGG [124,125], increasing the synthesis of tight junction proteins (claudins-3 and 4) in response to butyrate [126] and the CSF of L. plantarum RG14 [127].

Interestingly, the modulation of PI3K/AKT by postbiotics was observed in different cell types, which are not present in the intestine environment, thus extending the possible usage of postbiotics as potential drug candidates. For example, the injection of $L$. reuteri extract promoted wound healing in mice; this effect was dependent on $\mathrm{PI} 3 \mathrm{~K} / \mathrm{AKT} / \beta$-catenin/TGF $\beta 1$ pathway activation [128]. Moreover, the CSF of L. fermentum mitigated the induction of the $\mathrm{H} 2 \mathrm{O} 2$-induced senescence process in murine adipocytes via the inhibition of the PI3K/Akt/mTOR pathway [129].

\section{Molecular Targets of Postbiotics}

The majority of interactions between bacteria and hosts are mediated by a large heterogeneous group of receptors called PRRs. PRRs recognize molecules frequently found in pathogens, which are called pathogen-associated molecular patterns (PAMPs), or molecules released by damaged cells, called damage-associated molecular patterns (DAMPs) [130]. Documented PRRs that recognize postbiotic molecules include Toll-like receptors [131], nucleotide-binding oligomerization domain-containing protein (NOD)-like receptors [132], and C-type lectin receptors (CLRs) [133]. These receptors do not function in isolation; they cooperate with each other and with various co-receptors [134]. Here, we mainly focus on TRLs and NLRs, whereas the other receptors are only briefly mentioned.

\subsection{Toll-like Receptors}

Intestinal homeostasis is largely mediated by TLR signaling $[135,136]$ which serves as the main "communication channel" between the host and bacterial species inhabiting the intestine [137]. TLRs are type I membrane receptors present on immune cells (i.e., DCs, lymphocytes, neutrophils, and macrophages), epithelial cells, and neurons. They are localized at the cell surface or intracellular compartments, such as the endoplasmic reticulum (ER), endosome, lysosome, and endolysosome. They play a crucial role in the innate defense mechanisms against invading pathogens [138] and are activated by factors present in postbiotics. TLRs are composed of three structural elements: the cytoplasmic Toll/IL-1 receptor (TIR) domain that initiates downstream signaling [139], a single transmembrane helix, and the $\mathrm{N}$-terminal ligand recognition ectodomain. The ectodomain displays a horseshoe-like structure with leucine-rich repeats (LRRs) that mediate PAMP recognition (Figure 2).

TLRs can exist as monomers (e.g., TLR3, 5, 7, 8, 9, 11) or form homo- and heterodimers (e.g., TLR1, 2, 4, 6); different receptor configurations allow the recognition of diverse PAMPs of bacterial and viral origin. For example, TLR2/TLR1 heterodimers recognize triacyl lipopeptides compared to TLR2/TLR6 that recognize diacyl lipopeptides and LTA [111,112]. They also differ in triggering specific immune responses. TLR2/TLR6 may attenuate inflammatory/regulatory responses, whereas the TLR2/TLR1 complex may exert pro-inflammatory effects [113-115]; however, overall immune responses are still under discussion. Both TLR2/ 6 ligands [116,117] and TLR2/1 ligands [118] can induce opposing immune responses via these heterodimers. The key explanation for the broad diversity of observed results is probably a time-dependent structure-activity relationship between ligands and TLRs. Figure 3 shows the abundance of TLR configurations triggered by postbiotic molecules. Please refer to Table 2 for more details. 
Leucine-rich repeat (LRR) motif

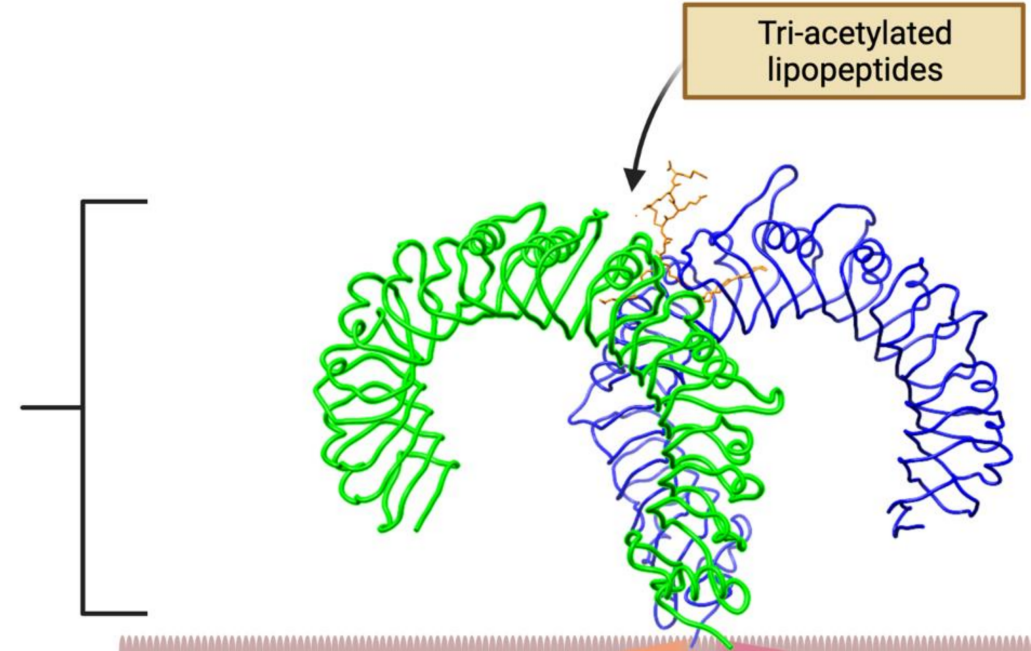

Transmembrane helix

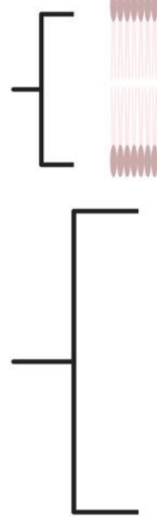

Intracellular TIR domain
Cell membrane

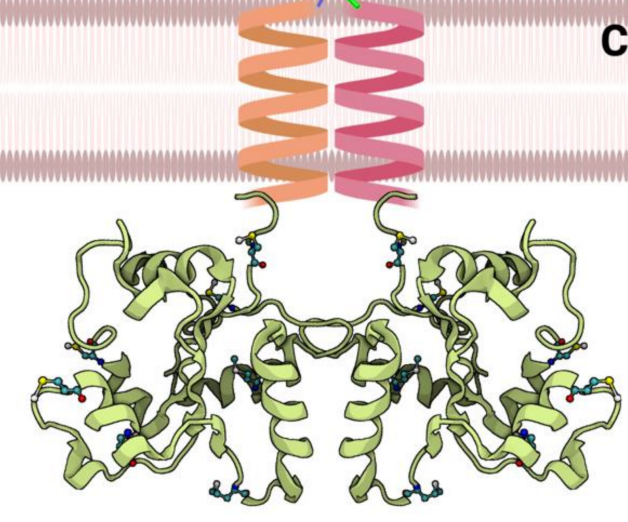

TLR1-TLR2

heterodimer

Figure 2. Schematic representation of the TLR structure. The main structural elements include: leucine-rich repeat (LRR) motif; transmembrane helix and intracellular TIR domain. The LRR structure is based on the model of the TLR1-TLR2 heterodimer (PDB ID: 2z7x) interacting with 6 tri-acylated lipopeptides, whereas the TIR domain homology model is based on the TLR2 TIR structure (PDB ID: 1fyw). Based on: [140]. Created with BioRender.com, accessed on 10 October 2021. 


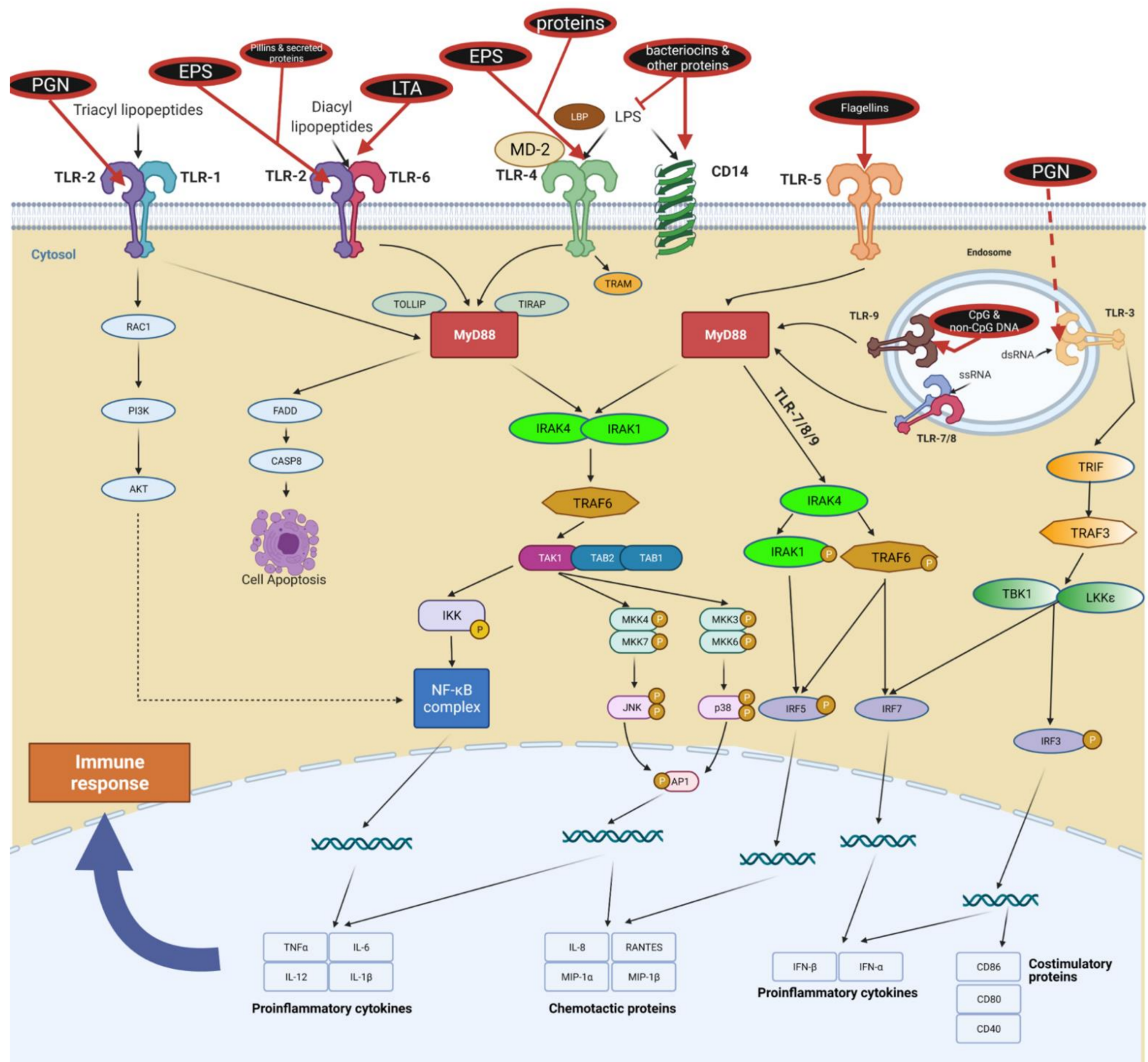

Figure 3. TLR pathways triggered by postbiotic molecules. Postbiotic ligands are presented in black ellipses with red borders and are connected with possible TLR receptors. For bacteriocins, the neutralizing effect on LPS was also highlighted by the red inhibition line. EPS — exopolysaccharides, PGN-peptidoglycan, LTA—lipoteichoic acid, CpG \& non-CpG DNA-Unmethylated CpG motifs, LBP-lipopolysaccharide binding protein, TOLLIP-toll-interacting protein, TIRAP-Toll/interleukin-1 receptor domain-containing adapter protein, TRAM-Translocating chain-associated membrane protein, MyD88-myeloid differentiation factor 88, RAC1-Ras-related C3 botulinum toxin substrate 1, PI3K - phosphoinositide-3 kinase, AKT—protein kinase B, FADD—Fas-associated protein with death domain, CASP8 — caspase-8, IRAK4/1—Interleukin-1 receptor-associated kinase 4/1, IRF3/5/7-interferon regulatory factor 3/5/7, TRIFTIR-domain-containing adapter-inducing interferon- $\beta$, TRAF3-TNF receptor-associated factor 3, TAK1-TAK1 mitogenactivated protein kinase kinase kinase, TAB1/2-TGF-Beta Activated Kinase 1/2. Created with BioRender.com, accessed on 10 October 2021. 
Table 2. The PRRs, subcellular localization, and recognized ligands. Adapted from [141].

\begin{tabular}{|c|c|c|c|}
\hline Receptor & Receptor Localization & Ligand & Origin of Ligand \\
\hline \multirow{5}{*}{ TLR2 } & \multirow{5}{*}{ Cell surface } & Lipoteichoic acid & $\mathrm{G}(+)$ bacteria \\
\hline & & Lipoprotein/lipopeptides & Various pathogens \\
\hline & & Hemagglutinin protein & Viruses (Measles Virus) \\
\hline & & $\begin{array}{c}\text { Glycosyl- } \\
\text { phosphatidylinositols }\end{array}$ & Parasites (Toxoplasma gondii) \\
\hline & & Exopolysaccharides & $\mathrm{G}(+)$ bacteria \\
\hline TLR2/1 & Cell surface & Triacyl lipopeptides & Bacteria and mycobacteria \\
\hline \multirow{2}{*}{ TLR2/6 } & \multirow{2}{*}{ Cell surface } & Diacyl lipopeptides & Mycobacteria \\
\hline & & Zymosan & Fungi \\
\hline TLR3 & $\begin{array}{l}\text { Cellular compartment } \\
\text { (endosomes) }\end{array}$ & dsRNA & Viruses \\
\hline \multirow{3}{*}{ TLR4 } & \multirow{3}{*}{ Cell surface } & Lipopolysaccharide & $\mathrm{G}(-)$ bacteria \\
\hline & & Envelope proteins & Viruses (Respiratory Syncytial Virus) \\
\hline & & $\begin{array}{c}\text { Glycosyl- } \\
\text { phosphatidylinositols }\end{array}$ & Parasites (Toxoplasma gondii) \\
\hline TLR5 & Cell surface & Flagellin & Bacteria \\
\hline TLR7/8 & $\begin{array}{l}\text { Cellular compartment } \\
\text { (endosomes) }\end{array}$ & ssRNA & Viruses \\
\hline TLR9 & $\begin{array}{l}\text { Cellular compartment } \\
\text { (endosomes)/cell surface }\end{array}$ & CpG-containing DNA & Bacteria and viruses \\
\hline \multirow{2}{*}{ TLR11 } & \multirow{2}{*}{ Cell surface } & $\begin{array}{c}\text { Uropathogenic bacteria } \\
\text { component }\end{array}$ & $\begin{array}{l}\text { Bacteria (uropathogenic Escherichia } \\
\text { coli) }\end{array}$ \\
\hline & & Profilin & Parasites \\
\hline NOD1 & Cell cytoplasm & Meso-diaminopimelic acid & PGN of $G(-)$ and some $G(+)$ bacteria \\
\hline NOD2 & Cell cytoplasm & Muramyl dipeptide (MDP) & PGN of $G(+)$ and $G(-)$ bacteria \\
\hline
\end{tabular}

G (+), Gram-positive; G (-), Gram-negative; dsRNA, double-stranded RNA; ssRNA, single-stranded RNA; PGN, peptidoglycan; Meso-DAP, $\gamma$-D-glutamyl-meso-diaminopimelic acid; MDP, muramyl dipeptide NOD1, nucleotide oligomerization domain-like receptor 1; NOD2 nucleotide oligomerization domain-like receptor 2.

TLRs are connected to multiple cellular pathways, such as NF-кB, interferon regulatory factors (IRFs), PI3K/AKT, and MAPK/ERK [142]. The signal is transduced downstream by specific adapter proteins, which have kinase, ubiquitinase, or ligase activity. Both TLR and their adapter proteins (e.g., MyD88) have TIR domains that mediate specific molecular interactions [143-145].

Most TLRs transduce signals via the myeloid differentiation factor 88 (MyD88) protein, which is a central node of inflammatory pathways [146]. One exception is TLR3, which mediates signaling directly through the TIR-domain-containing adapter-inducing interferon- $\beta$ (TRIF) pathway [142]. TLR4 is also unique in that it can activate both MyD88and TRIF-dependent pathways [142]. This double activation is cooperative and results in the balanced production of both pro-inflammatory cytokines and type I interferons (IFNs), specifically IFN $\beta[142,147,148]$. Thus, TLR4 is the only non-nucleic acid-recognizing receptor that triggers a type I interferon response.

Finally, TLRs cooperate with other receptors; for example, TLR activation may be enhanced by the activation of tyrosine kinase Bkt [149] or mediated by endosomal MHC Class II complexes $[150,151]$. Bacterial peptides are present on MHC class II complexes and may act as adjuvants in TLR-dependent innate responses. Bioinformatics analysis revealed that multiple peptides from commensal bacteria showed an affinity toward MHC complexes, possessing putative immunomodulatory effects [152]. 
Postbiotic interactions with TLRs seem to be dependent on ligand structure. However, interactions are not restricted to a single ligand-single TLR. Ultimately, the signaling outcome is a result of multiple ligand-receptor events occurring simultaneously, e.g., peptides presented on MHC and LTAs bound to TLR2/TLR6. This overall effect gives rise to a strain-dependent unique immune response. Below we discuss the most prominent ligands, and show how their structural features could be involved in TLR signalling.

\subsubsection{TLR Ligands: LTA}

One of the most extensively studied ligands present in postbiotics is LTA. Produced by Gram-positive bacteria, LTA is somewhat falsely considered an equivalent of LPS (synthesized by Gram-negative bacteria). LPS mediates the pro-inflammatory response via the TLR4/CD14/MD2 pathway, whereas LTA is mainly recognized by TLR2/TLR6 heterodimers with CD14 and CD36 as coreceptors.

Response to LTA varies from anti-inflammatory to proinflammatory (immunostimulatory) and strongly depends on its chemical and structural composition. For example, LTA from L. casei YIT9029 and L. fermentum YIT0159 induce a proinflammatory response through TLR2 receptors, which results in TNF- $\alpha$ expression in macrophages [153]. However, LTA from $L$. plantarum exerts an anti-inflammatory action in monocytic cells and decreases TNF- $\alpha$ production [154-156].

Multiple structure-activity relationship (SAR) studies have been conducted with LTA derived from different bacterial species (both probiotic and pathogenic) and with synthetic LTAs. Three main structural modifications influencing LTA activity profiles have been revealed [49]. The removal of D-alanine in L. rhamnosus GG enhanced the anti-inflammatory potential in murine colitis models [157]. A similar effect was observed by changing Dalanine to glucosyl substitutions in L. plantarum [158]. Additionally, decreasing the degree of saturation of acyl chains in the glycolipid moiety of LTA enhanced its anti-inflammatory properties [159]. For structural details, see the summary Figure 6. From the drug discovery perspective, the possibility to select and/or modify LTA to adjust inflammatory effects is encouraging. Although the role of LTAs in modulating immune responses is significant, their influence is too weak in relation to the observed cumulative effect [49].

\subsubsection{TLR Ligands: Flagellins}

Flagellins are bacterial helical proteins, which are the main structural element of the bacterial locomotion organelle flagellum. They are recognized by TLR5 [160] and by the interleukin-1 $\beta$ (IL-1 $\beta$ ) converting enzyme (ICE) protease activating factor (IPAF) [161,162]. The TLR5 receptor is mainly present on the basolateral side of intestinal epithelial cells; thus, by recognizing flagellins, it informs whether bacteria have passed through the intestinal epithelium [163]. TLR5 is strongly engaged in the microbiome-host crosstalk, shaping the overall bacterial community [164] and boosting immune system maturation [165].

TLR5 regulates the production of anti-flagellin immunoglobulins, which help maintain tolerance to commensal bacteria by suppressing flagellin gene expression in many bacterial species. Improper recognition of bacterial flagellins is considered one of the factors associated with IBD [166,167], similar to excessive TLR5 stimulation, which disrupts intestinal barrier integrity [168]. Additionally, a few studies reported that TLR5 may influence metabolic cascades in vivo; TLR5-KO mice, or impaired flagellin recognition, resulted in metabolic syndrome [169], changes in the composition of the intestinal microflora, impaired fat metabolism, and inflammation [170]. However, the exact metabolic influence of TLR5 is still under discussion [171].

Flagellins produced by different strains of lactic acid bacteria seem to have a wide spectrum of immunological activity. For example, flagellins isolated from commensal L. ruminis induced pro-inflammatory IL-8 production in human colonic epithelial cell lines via TLR5-dependent mechanism [172]. However, flagellins isolated from a different genus, L. agilis, did not enhance IL-8 production in Caco-2 cells. Generally, flagellins isolated 
from Lactobacillus strains were less inflammatory compared to pathogenic strains such as S. typhimurium.

These results can be explained by structural differences between the commensal and pathogenic flagellins. Most of the amino acid residues are conserved between flagellins; however, S. typhimurium and L. monocytogenes have the L-Q-R motif in the recognition site of TLR5, whereas L. ruminis and L. agilis have the L-G-R and L-N-R motifs, respectively, which decrease the binding and activation of TLR5 [173]. These structural differences are possibly an evolutionary adaptation, present in many commensal bacteria, to decrease immunological activation and reduce clearance by host defense mechanisms [174].

As a postbiotic, flagellins have been shown to mediate pro-health effects. For example, in a state of impaired immunity, flagellins of the probiotic E. coli Nissle 1917 increased the expression of the human antimicrobial peptide $\beta$-defensin 2 (BD2, also known as DeFB4) by intestinal epithelial cells, enhancing host defense systems against pathogens [175].

Flagellins-TLR5 interactions exert effects on immunological homeostasis through protection against bacterial infection. From this point, the exploitation of TRL5 structural motifs to develop an antagonist or a partial agonist compound could be potentially interesting. A key property of partial agonists is that in the presence of a full agonist (bacterial stimuli), they will compete for the same receptor and thereby reduce the ability to produce the maximum effect.

\subsubsection{TLR Ligands: Other Cell Wall-Associated Proteins and Fimbriae}

Besides flagellins, other microbial cell-surface proteins may interact with TLRs. Pili (fimbriae) are small, fibrous, surface proteins present in both Gram-negative and Grampositive bacteria. Mostly characterized in pathogens, they act like virulence factors promoting host-cell adhesion and pathogenesis [176,177]. In commensals, pillins are suggested to provide some beneficial properties to a host [178-181].

Pili may directly or indirectly interact with TLRs and modulate immune responses. The work on the influence of SpaCBA pili on the immune response in vitro, using different knockout models of L. rhamnosus LGG, showed it depends greatly on the interplay between pili and other cell wall elements such as LTA [180].

Furthermore, while the reduction of SpaCBA expression in L. rhamnosus LGG elevated IL-8 production in Caco-2 cells, the overexpression of the SpaCBA pilus dampened IL-8 expression [180]. These interactions are mediated via TLR2 receptors. Overall, the authors suggested that pili may function as regulators of IL-8 expression by attenuating the effects induced by other surface molecules, such as LTA.

Finally, an interesting example of an indirect interaction between cell wall-associated proteins and TLRs is the elongation factor $\mathrm{Tu}(\mathrm{eFTu})$ and chaperone protein GroeL (also known as GroL). Originating from L. johnsonii La1, these two multifunctional proteins were shown to stimulate IL-8 secretion in IECs in a CD14-dependent manner [182,183]. CD14 is a co-receptor that is thought to function as a signal amplifier by inducing TLR4 endocytosis and activating TRIF-dependent pathways, leading to the production of type-I IFNs [184,185].

\subsubsection{TLR Ligands: Oligonucleotides}

Unmethylated CpG motifs found in bacterial and viral DNA, double-strand RNA (dsRNA), single-strand (ssRNA), and specific oligonucleotide sequences are present in high amounts in the intestine [186]. These PAMPs act as activators of the endosomal TLR9, present in multiple immune cells (e.g., DCs and B cells), in IECs, and also in various lung cells [187-189]. TLR9 is especially engaged in shifting immunological responses between Th1 (INF- $\gamma$ producing) and Th2 (mainly producing IL-4) lymphocytes and in the maintenance of immunological homeostasis in the intestine [136].

The immunomodulatory effect of unmethylated CpG motifs depends on their structure, origin, and physiological conditions. Some of the most notable features of $\mathrm{CpG}$ motifs influencing TLR9 activation are thymidine content, flanking sequences, backbone 
type, presence of a $5^{\prime}-\mathrm{TC}$, poly-G sequence, length, and concentration [190]. These are used to design synthetic oligonucleotides with targeted activity, such as adjuvants in vaccines [191,192].

To date, a few probiotic CpG motifs have been characterized, mostly from Lactobacilli and Bifidobacterium. L. rhamnosus LGG-derived oligonucleotides display immunostimulatory potential by increasing the IFN- $\gamma / \mathrm{IL}-4$ ratio. This skewed the lymphocyte differentiation from Th2 to Th1 and improved intestinal barrier function in a mice model of allergy [193]. This is in line with previous experiments, where LGG CpG motifs induced the Th1 response and the production of cytokines (INF- $\gamma$, IL-6, IL-12, IL-18, and TNF- $\alpha$ ) $[194,195]$. The GTCGTT sequence, which has been proposed to have strong immunostimulatory effects, is frequently present in the genomes of L. casei, L. plantarum, L. rhamnosus, and Bifidobacteria [196]. It has been proposed that genomic DNA contributes to about $50 \%$ of the immunomodulatory effects of living probiotics $[197,198]$. Some studies using isolated $\mathrm{CpG}$ motifs provide insight into the mechanisms of modulating allergic responses of probiotic strains [199,200]; however, human studies with CpG motifs as single ligands are still lacking.

However, probiotic-derived oligonucleotides may also exert an anti-inflammatory effect, for example, via the inhibition of NF-kB in intestinal epithelial cell lines [97]. Another report showed that gDNA and CpG motifs significantly decreased the LPS-induced IL-6 mRNA levels in RAW264.7 macrophages [201]. Importantly, oligonucleotides derived from bacteria can differ in activity due to the experimental conditions, such as the presence or absence of inflammatory stimuli. Namely, the pretreatment of THP-1 monocytic cells with L. plantarum gDNA attenuated the pro-inflammatory effect of LPS administration. However, when administered alone, gDNA had the opposite effect [202].

In summary, similar to other postbiotic TLR ligands, oligonucleotides have a wide spectrum of activity. Depending on the origin, sequence/structure, and physiological conditions, they may augment or attenuate inflammatory responses.

\subsubsection{TLR Ligands: Bacteriocins}

Antimicrobial peptides (AMPs), or bacteriocins, are one of the secreted protein fractions produced by bacteria. AMPs are secreted to fight other bacteria competing for the same ecological niche [203]. AMPs can also act as signaling (quorum sensing) or colonizing peptides, and importantly, they can shape the overall microbiome community [204]. The ability to synthesize AMPs is a desirable feature of probiotic strains, which influences their survival in the human gastrointestinal tract [204-206].

In higher organisms, AMPs are important components of innate immunity, protecting the host against infections. The presence of commensal AMP-producing strains in intestines was confirmed by biochemical $[207,208]$ and genetic studies [209,210]. Notably, AMPproducing strains seem to be predominant in the human microbiome $[207,211]$.

Multiple studies have reported the immunomodulatory potential of AMPs, which enhance or attenuate immune responses in the gut at multiple levels of the cell's signaling pathways [212-218]. Most frequently, the observed outcome was a result of an indirect effect of AMPs on TRLs, that is, through binding (and neutralizing) their natural ligands (i.e., IPS, LTA, lipoproteins, and oligonucleotides) [219]. Bacteriocins, which are mostly cationic, bind to anionic elements of the bacterial cell wall (i.e., LPS) through electrostatic interactions [141]. For example, an increase in hydrophobic properties via amino acid substitution enhanced the binding of human cathelicidin CAP18/LL-37 analogues to LPS [220]. Nisin, a bacterial AMP, may bind and neutralize LPS [221]. This effect may explain previously observed immunomodulatory results obtained with Nisin and other bacteriocins tested in the presence of LPS [222-227]. Similarly, human AMP, LL-37, neutralizes LPS, reducing the activation of the TLR4 and TLR2/1 heterodimers [214,228]. Interestingly, LL-37 is also engaged in direct interactions with cell surface receptor CD14 [220,229,230], suggesting the involvement of both direct and indirect mechanisms of action. Recently, local administration of nisin in an animal model of clinical endometritis lead to alter- 
ations in the cytokines' (B7-2, IFN- $\gamma$, IL-2, and IL-8) expression profile and prevented Staphylococcus aureus infection-induced endometrial changes in uterine tissue, similarly to administration of kanamycin [231].

Taken together, the administration of bacteriocins may be a promising alternative or complement to classic antibiotics. These properties, such as LPS-neutralizing potential and anti-microbial activity, seem to be strictly connected to structural features.

\subsubsection{TLR—Not Only Intestine Receptors}

The role of TLRs in health and disease is not restricted to immunological reactions. TLR4 and TLR2 were found on intestinal nervous cells and smooth muscle cells, influencing intestinal motility $[232,233]$. TLR4 and TLR5 are proposed as two main receptors engaged in liver inflammation [234], diet-induced liver diseases [235], and hepatocellular carcinoma [236-238]. Postbiotic ligands such as bacteriocins may cross the intestinal barrier and act beyond the intestines $[239,240]$.

TLRs are one of the most engaged receptors in sensing postbiotic-derived factors. Bacterial proteins, peptides, LTA derivatives, polysaccharides, and nucleic acids can all trigger TLR signaling. The exerted physiological effect is a result of the diverse interactions that a "cocktail of molecules" provides and may have a negative or beneficial influence on human health. The key factor determining postbiotic ligand activity seems to be strain specificity. In addition, TLRs are not only intestinal or immunological receptors; they also play physiological roles in other tissues. These properties open new routes for the possible application of postbiotic molecules as potential drug candidates.

\subsection{NOD like Receptors (NLR)}

NOD receptors (nucleotide-binding oligomerization domain-like receptors, nucleotidebinding leucine-rich repeat receptors, or NLRs) are crucial intracellular receptors involved in innate immune responses. NLRs are capable of interacting with various PAMPs present in postbiotics [241-243]. NLRs' interaction with the host microbiome was recently extensively reviewed [244]. Here, we focus on the two main postbiotic sensors, NOD1 and NOD2, and briefly introduce inflammasomes as important communication hubs between the host and microbiome.

The human NLR family consists of 22 proteins, including NOD-like receptors and several proteins serving as scaffolds in forming multiprotein complexes termed "inflammasomes" $[245,246]$. NLRs are expressed in many cell types, including immune cells (mainly macrophages and neutrophils) and epithelial cells. Their expression can differ between cells, e.g., NOD1 is expressed in multiple cell types comprising the intestinal epithelium and DCs, whereas NOD2 is not detected in intestinal epithelial cells [247]. NOD1 and NOD2 (Figure 4) are both multi-domain proteins consisting of a variable N-terminal effector region, caspase recruitment domain (CARD), a centrally located NOD domain that is critical for activation (known as NACHT or NBD), and C-terminal LRRs that sense PAMPs [132]. The main structural difference between NOD1 and NOD2 is the number of CARD domains, being single in NOD1 and double in NOD2 [248].

Contrary to TLRs, NOD-like receptors are located intracellularly and recognize ligands, which translocate into the cytosol after phagocytosis and degradation in phagolysosomes. NOD1 recognizes $\gamma$-d-glutamyl-meso diaminopimelic acid (DAP) from Gram-negative bacteria, whereas NOD2 can detect muramyl dipeptide (MDP) from both Gram-positive and Gram-negative bacteria [249]. NOD1 and NOD2 are activated through direct ligand binding, which leads to self-oligomerization. This allows for the interaction of the Nterminal domain with receptor-interacting serine/threonine protein kinase 2 (RIPK2), which in turn induces pro-inflammatory response cascades via MAPK and NF- $\mathrm{kB}$ pathways (Figure 5). 
a)
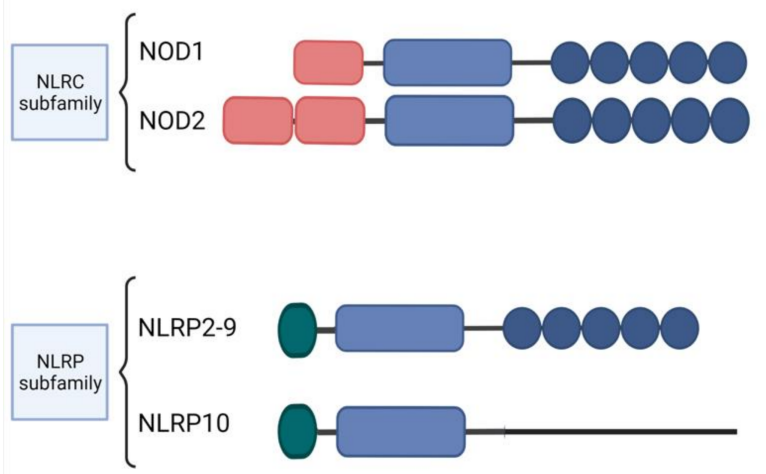

CARD
Pyrin

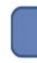

b)

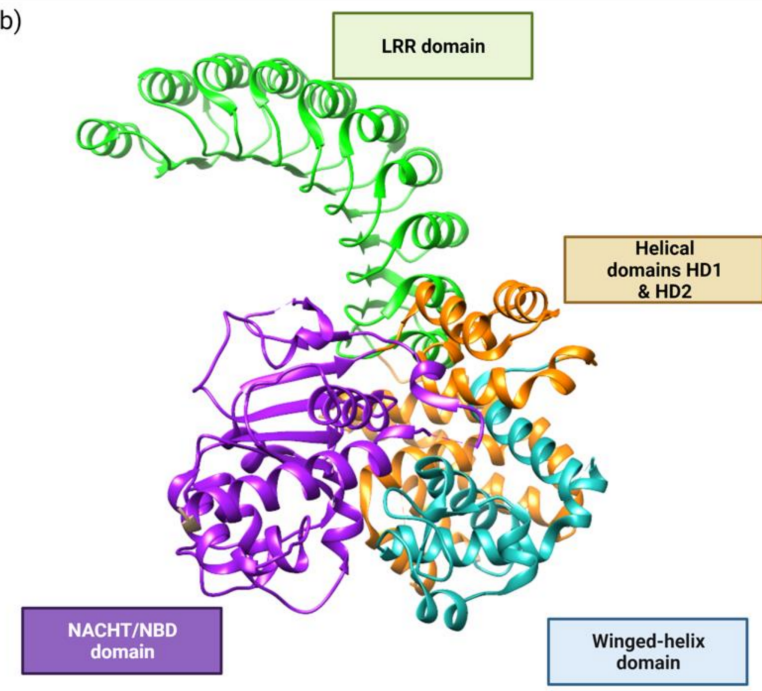

Figure 4. Structure of the NLR receptors. (a) Structural differences between the NLR protein family. NOD1/2 are members of the NLRC subfamily containing the CARD domain. The pyrin domain is characteristic for the NLRP family, whose main members are inflammasomes, and can additionally differ in the LRR region. (b) NOD2 receptor structure (PDB ID: 5iam) with ribbon representation of the main domains: LRR (leucine rich repeats), NACHT/NBD (nucleotide binding domain) and Helical domains. Created with BioRender.com, accessed on 10 October 2021.

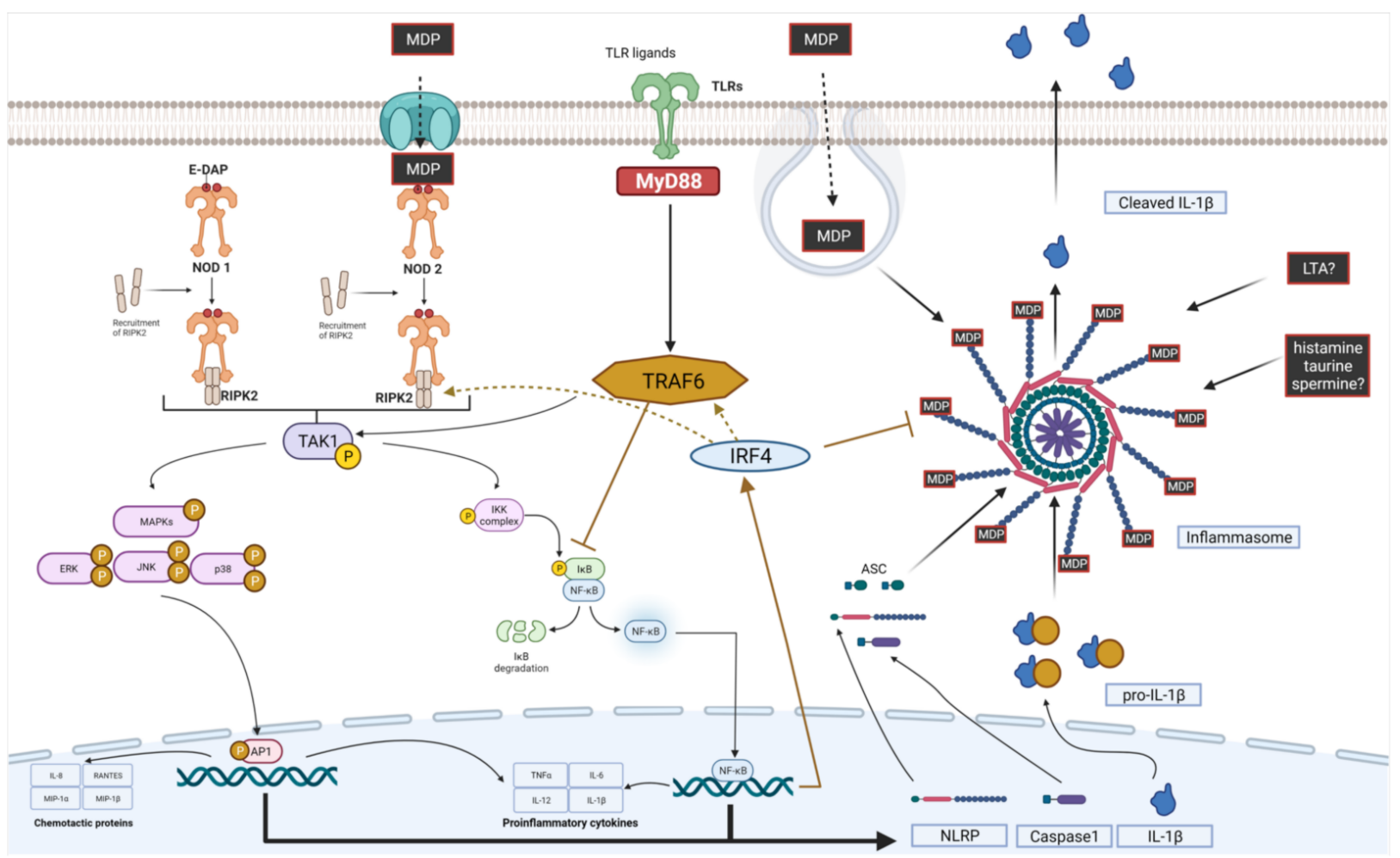

Figure 5. The interaction between TLR and NLR cascades in recognition of postbiotic ligands (black squares with red border). The signalling cascade of NOD1/2 receptors with TLR and inflammasome pathways is shown. NOD2 signaling cascade increases expression of IRF4 (yellow arrow), which binds to TRAF6, inhibits poly-ubiquitination of RIPK2 kinase (yellow dash arrows) and inhibits NF-KB activity (yellow inhibition line). IRF4 may also have suppressor activity against inflammasomes, described in [250]. NOD2 receptors are able to regulate the expression of inflammasomes constituents: NLRP, Caspase1 and IL-1ß [251]. Created with BioRender.com, accessed on 10 October 2021. 


\subsubsection{NOD and the Microbiome Crosstalk}

NOD receptors are crucial PRRs in communication between the host and microbiome. NOD1 receptors are involved in recognizing and shaping the bacterial community by regulating the host immune response through AMP synthesis [252]. Knocking out Nod1 leads to the disruption of intestinal barrier integrity, enhanced inflammatory response, and inflammation-mediated tumorigenesis. Notably, the depletion of gut microbiota suppressed the observed pathology [253]. NOD2 regulates the number, size, and T-cell composition of Peyer's patches (PPs), which are a part of gut-associated lymphoid tissue (GALT) [254]. In turn, T-cells present in the PP can modulate paracellular and transcellular permeability, and as a result, bacteria migrate from the gastrointestinal tract to extraintestinal sites $[254,255]$. NOD2-deficient mice showed an altered microbiota composition [256,257], increased transcellular permeability, and pathological changes in immune cells $[255,258]$. Notably, mutations in Nod2 genes are associated with increased susceptibility to Crohn's disease (CD) $[259,260]$, highlighting its immune-microbiome crosstalk association.

\subsubsection{Other Regulatory Roles of NOD Receptors}

Both NOD1 and NOD2 seem to be implicated in other processes beyond immune responses. From a therapeutic point of view, modulation of insulin homeostasis seems promising, where NOD2 may play a protective role, contrary to NOD1. For example, knocking out Nod1 lowered the levels of macrophage-induced adipose tissue inflammation and neutrophil recruitment $[261,262]$. However, depletion of NOD2 receptors had the opposite effect; it enhanced adipose tissue and liver inflammation and exacerbated insulin resistance [263]. Similar conclusions were drawn from studies where the NOD1 ligand (FK565) induced whole-body insulin resistance, whereas the NOD2 ligand (peptidoglycan) had a protective effect on mice fed a high-fat diet [261,263]. This effect depends on interferon regulatory factor 4 (IRF4) activation, which plays a role in NOD2, but not in the NOD1 signaling cascade (Figure 5) [264]. The activation of NOD2 leads to increased IRF4 expression and binding to TNF receptor-associated factor 6 (TRAF6) and RIPK2. This inhibits the polyubiquitination of TRAF6 and RIPK2 and results in the down-regulation of NF- $\mathrm{KB}$ [265]. Recently, the selective activation of RIPK2 has been proposed as the second molecular mechanism of NOD2-mediated improvement in glucose tolerance. These effects were observed on non-hematopoietic cells and suggest that this mechanism is cell-type dependent [266].

\subsubsection{NOD and Postbiotic Molecules}

Several studies suggest that the bacterial cell wall component, peptidoglycan (PGN), and NOD receptor interactions are greatly responsible for the strain-specific effects of probiotics [267-269]. After the administration of PGN into immunocompromised mice, the respiratory and systemic adaptive humoral responses measured as cytokine levels improved $[270,271]$. Systemic stimulation of NOD1 by microbiota-derived PGN led to enhanced systemic immunity [252]. A growing body of evidence suggests that the observed immunological effects are directly connected with the chemical structure of PGN. Below, we summarize some of the modifications in the structure of PGN defining the immunomodulatory potential of bacteria (Figure 6).

PGNs have a polymeric structure and contain layers of muramyl dipeptide (MDP). The obligatory unit of MDP recognized by NOD2 is N-acetylmuramic acid (MurNAc) [272]. Multiple bacteria can modify the structure of MDP, which helps to reduce PRR presentation and immune system activation. The known modifications include the following:

- $\quad \mathrm{N}$-deacetylation of the sugar backbone; this is the most common modification in Gram-positive bacteria [273], which reduces lysozyme degradation and the activation of NOD and the NLRP3 inflammasome [273,274]. 
- The amidation of the $\varepsilon$-carboxyl group of meso-diaminopimelic acid (mDAP) or the amidation of the $\alpha$-carboxyl group of glutamic acid reduces lysozyme degradation and NOD1 activation. This has been reported for some L. plantarum strains $[275,276]$.

- O-acetylation of MurNAc reduces the degradation of PGN by lysozymes, resulting in the lower presentation of MDP fragments and reduced NOD signaling [273,277].

- The polysaccharide-PGN complex (connected by phosphodiester bond), described for the first time in L. casei Shirota (LcS) [278], suppresses IL-6 production via the inhibition of NF- $\mathrm{kB}$ phosphorylation and enhances NOD2 mRNA levels in RAW264 macrophages in vitro [279]. Furthermore, it provides resistance to lysis, which determines amplified IL-12 production in macrophages. This effect is observed only for intact cell walls consisting of PGN and cell wall polysaccharides. Purified PGN has a weak ability to induce IL-12 production, whereas minimal structural units of PGN (6-O-stearoyl-muramyl dipeptide) abolish the effect of intact cell walls [247].

The above-mentioned influence of polysaccharide-PGN on the production of IL-12 was shown to be mediated by both TLR2 and NOD2, suggesting a dual mode of action of PGN [280]. However, direct (and selective) interaction between PGN and TLRs is still debated [281]. L. salivarius Ls33 induces the development of CD103+ DCs and CD4+ Foxp3+ regulatory T cells in an IL-10-dependent manner without any TLR involvement [50]. However, PGNs from L. rhamnosus CRL1505 exert their immunostimulatory potential via TLR3 [282]. TLR2 and NOD2 interplay in PGN recognition, which is crucial in response to many Lactobacilli strains $[268,283]$. Despite this controversy, the above studies indicate that the structure of PGN defines recognition and affinity to its biological target(s).

\subsubsection{Inflammasomes and Postbiotic Molecules}

Besides NOD receptors, the other group classified as NLR proteins are inflammasomes. Inflammasomes are multiprotein, cytosolic innate immune signaling complexes that sense different stimuli and may lead to the activation of caspase 1. They are expressed in multiple cell types and are able to recognize both intrinsic and extrinsic stimuli. The best-described inflammasomes involved in microbiome-host interplay are NLRP3, NLRP6, and NLRP12 [284].

NLRP3 seems to play a protective role in IBD [285], colorectal cancer [286], and maintaining proper balance in the gut environment via the regulation of IL-1 $\beta$ and AMP secretion [287]. NLRP6, preferentially expressed in goblet cells and enterocytes, is involved in similar processes: host defense against infection, autoimmune responses, tumorigenesis, and intestinal homeostasis. However, how and when NLRP6 modulates host-microbiome crosstalk is still under discussion [283].

Inflammasomes are also engaged in systemic processes, i.e., renal inflammation (NLRP3 and NLRP6) [288,289] and the gut-brain axis (NLRP3) [290]. It was shown that NLRP12 may have a systemic influence on microbiome composition, leading to various metabolic imbalances. Knocking out the NLRP12 gene causes a significant reduction of the SCFA-producing Lachnospiraceae phylum, which may provoke obesity and the development of metabolic syndrome [291].

Inflammasomes are sensitive to microbiome ligands. NLRP3 seems to be engaged in butyrate sensing as a hub protein mediating negative symptoms in IBD [292]. NLRP6 recognizes LTA from Gram-positive bacteria and shares common ligands with TLRs. The activation of NLRP6 by LTA, originating from pathogenic bacteria, leads to excessive IL-18 release, which exacerbates infection [293]. This is caused by the suppression of NF- $\mathrm{kB}$ signaling, which in turn attenuates the inflammatory response, i.e., dampens cytokine, chemokine, and cell surface protein expression. Interestingly, the NLRP6-LTA interaction leads to an excessive inflammatory response, but mild stimulation may be protective [294]

Microbiota-associated metabolites, such as taurine, histamine, and spermine, may modulate NLRP6 inflammasome signaling, epithelial IL-18 secretion, and downstream AMP profiles, resulting in the improvement in barrier integrity [295]. However, similar to the LTA case, histamine dosage is crucial; excessive exposition may induce an inflammatory 
response mediated via the histamine 2 receptor [296,297]. In summary, inflammasomes are engaged in recognizing postbiotic ligands and are an important part of overall response to PAMPs. They can recognize small molecules (e.g., amino acids) and more complex structures like LTA or LPS. More research is needed to elucidate a more clear structureactivity relationship between ligands and NLRPs [298].

\subsubsection{NLR and TLR Interplay}

There is a high degree of bidirectional crosstalk between NLR and TLR receptors, which fine-tunes the final immune response (Figure 5). NODs and TLRs can act in tandem by recognizing different bacterial ligands and transmitting signals through intestinal cells. They activate similar hub proteins responsible for the inflammatory response (NF-kB, AP-1, and IRFs), which results in an augmented and more targeted response to bacterial infection. NOD ligands, such as DAP and MDP, along with ligands recognized by TLRs, exert a synergistic effect on the expression of proinflammatory cytokines in human immune cells [256,299-301].

However, in vivo studies suggest a more complicated interplay. In mice overexpressing NOD2 receptors, the administration of MDP reversed increased transcellular permeability induced by TLR2 (agonist: Pam3CSK4) and TLR4 (agonist: LPS). In NOD2KO mice, TLR2 and TLR4 expression was elevated in basal conditions, which suggests the involvement of NOD2 in the regulation of TLR expression [255]. These results indicate that NOD2 may also dampen the inflammatory activity of TLR pathways, which results in a more balanced overall immune response.

Both TLRs and NLRs are also engaged in intestinal angiogenesis, and bacterial ligands for NOD1/2 and TLR2/4/6 stimulate the production of angiogenic factors. Knocking out RIPK2 and TRAF6 (a common hub protein for both pathways) inhibited the observed results [302].

NLR and TLR cellular effects are rather analogous, as both families act through similar and well-known pathways. The picture changes, however, when in vivo studies are conducted. Where cellular and tissue interplay occurs, a less obvious, dose-dependent, bifurcated, and bidirectional interplay is unraveled (Figure 5).

\subsection{Other Receptors}

There are a number of receptors expressed on intestinal cells that may interact with bacterial molecules (Table 3). SCFRA receptors (GPR43, GPR41, GPR109a, and Olfr78), the pregnane $X$ receptor $(\mathrm{PXR})$, and the aryl receptors $(\mathrm{AhR})$ are all interesting targets from the drug discovery point of view. However, due to the new definition of postbiotics, where metabolites are no longer classified under this term [23], they are only briefly described in Table 3. In this section, we introduce c-type lectin receptors (CLR) with a special focus on DC-specific ICAM3-grabbing non-integrin (DC-SIGN) receptors, which is the best-described member of this family, regarding postbiotic recognition.

Table 3. Other possible host receptors and their postbiotic ligands.

\begin{tabular}{|c|c|c|c|}
\hline Receptor & Ligand & Outcome & Reference \\
\hline EGFR & $\begin{array}{l}\text { p40 and p75 } \\
\text { plantaricin P1053 }\end{array}$ & $\begin{array}{l}\text { phosphorylation of Akt and ERK } \\
\text { kinases; increased viability of } \\
\text { non-cancerogenic cells }\end{array}$ & [303-305] \\
\hline $\begin{array}{l}\text { formyl peptide receptors } \\
\text { (FPRs) }\end{array}$ & $\begin{array}{l}\text { N-formyl-Met-Leu-Phe; HK } \\
\text { Lactobacillus }\end{array}$ & $\begin{array}{l}\text { ERK phosphorylation without } \\
\text { stimulating pro-inflammatory } \\
\text { phospho-IKB or pro-apoptotic } \\
\text { phospho-c-Jun NH2-terminal kinase }\end{array}$ & [306] \\
\hline
\end{tabular}


Table 3. Cont.

\begin{tabular}{|c|c|c|c|}
\hline Receptor & Ligand & Outcome & Reference \\
\hline $\begin{array}{l}\text { formyl peptide receptor-like } 1 \\
\text { (FPRL1) }\end{array}$ & human bacteriocin LL-37 & $\begin{array}{l}\text { upregulated angiogenesis via } \\
\text { increased intracellular calcium levels }\end{array}$ & [307] \\
\hline CCR6 & $\begin{array}{l}\text { human bacteriocins } \\
\text { beta-defensins }\end{array}$ & $\begin{array}{l}\text { increased chemotaxis of dendritic and } \\
\text { T cells }\end{array}$ & [308] \\
\hline pregnane $\mathrm{X}$ receptor (PXR) & $\begin{array}{l}\text { Indole derivatives (i.e., } \\
\text { Indole-3-propionic acid) }\end{array}$ & $\begin{array}{l}\text { improved tight junction functions by } \\
\text { increased expression of claudins and } \\
\text { occludins }\end{array}$ & {$[39]$} \\
\hline aryl hydrogen receptors (AhRs) & indole-3-lactic & increased Il-22 expression & [40] \\
\hline $\begin{array}{c}\text { Short chain fatty acid receptors } \\
\text { (GPR43, GPR41, GPR109a and } \\
\text { Olfr78) }\end{array}$ & $\begin{array}{l}\text { Short chain fatty acids (i.e., } \\
\text { butyrate, propionate) }\end{array}$ & $\begin{array}{c}\text { modulates AMP-kinase and NF-кkB } \\
\text { activity regulates glucose } \\
\text { homeostasis, immune processes, } \\
\text { permeability of cell membrane, } \\
\text { oxidative status, } \\
\text { cell cycle or brain functions }\end{array}$ & [309-312] \\
\hline
\end{tabular}

\section{C-Type Lectin Receptor (CLR)-DC-SIGN}

CLR are PRRs that recognize specific motifs from bacteria, viruses, and fungi. The family consists of 17 different subgroups classified according to structural differences with a common domain: lectin. The lectin domain can recognize a wide spectrum of glycans from pathogens, commensals, or host proteins. Under some circumstances, CLRs can also recognize certain proteins and lipids [313]. CLRs are expressed mainly on myeloid cells and to a lesser extent on other immune cells [314,315]. They play a role in immunological processes, such as cell-cell adhesion, autophagy, and apoptosis. CLRs also have the ability to orchestrate immune responses to commensal and pathogenic bacteria by regulating gene expression and modulating TLR signaling [133,313,316-318]. They are one of the biggest groups of PRRs, engaged in recognition of a whole spectrum of pathogen and commensal associated molecules. They are also less studied when compared to NLRs or TLRs.

The most commonly described receptor, considering postbiotic recognition, is DCSIGN. This transmembrane receptor is present on intestinal cells (especially myeloidand monocyte-derived DCs), endothelial cells, and specific subpopulations of macrophages [319-321]. It recognizes high mannose- and fucose-containing regions on polysaccharides and proteins, which leads to the activation of serine/threonine kinases RAF-1, the acetylation of the induced NF-KB subunit p65, and finally affects cytokine expression, e.g., the upregulation of IL-10 [322].

According to the above work, bacterial exopolysaccharides (EPS) rich in mannose and fucose seem to be natural ligands for DC-SIGN. Unfortunately, it is difficult to draw clear conclusions concerning DC-SIGN-EPS interactions. This is due to different isolation and purification methods. There are also no studies confirming the direct involvement of DC-SIGN receptors in the mentioned interaction [323,324]. Nevertheless, in many studies on EPS [325-328], an increase in the production of IL-10 has been observed, which may indicate involvement of CD-SIGN/RAF-1/p65. Studies on EPS revealed that the main receptors engaged in EPS-immunomodulatory properties are TLR2 or TLR4 [329]. Similar observations have been published for Bifidobacterium animalis subsp. lactis [324] and for LGG-derived EPS [57]. At this moment, these findings do not rule out the engagement of DC-SIGN or DC-SIGN-TLR tandem [330].

Importantly, glycosylation may affect the activity of various postbiotic ligands. For example, in the case of pili, which are TLR ligands, glycosylation expands their affinity toward DC-SIGN receptors [331]. Indeed, mannose and fucose residues on SpaCBA pili from L. rhamnosus GG can interact with DC-SIGN receptors on DCs [331]. This leads to the induction of different types of cytokines compared to non-glycosylated pili recognized by TLR2 (Figure 6). 
S-layer proteins have been reported as other DC-SIGN ligands [46,47]. S-layers form two-dimensional protein arrays that are located at the outermost surface of bacteria walls [332]. They exert multiple biological functions, including cell wall synthesis, control of cell division, mechanical and osmotic stabilization, $\mathrm{pH}$ balance, and bacteriophage protection [332,333]. They possess high structural diversity and are extensively glycosylated. The structure of S-layer proteins defines their affinity to DC-SIGN receptors or TLR/DC-SIGN tandems [45,334]. Moreover, downstream cytokine expression differs between different types of S-layer proteins; L. acidophilus NCFM SlpA induces IL-10 and IL-12p70 production, whereas SlpB induces IL-12p70, TNF, and IL-1 [334].

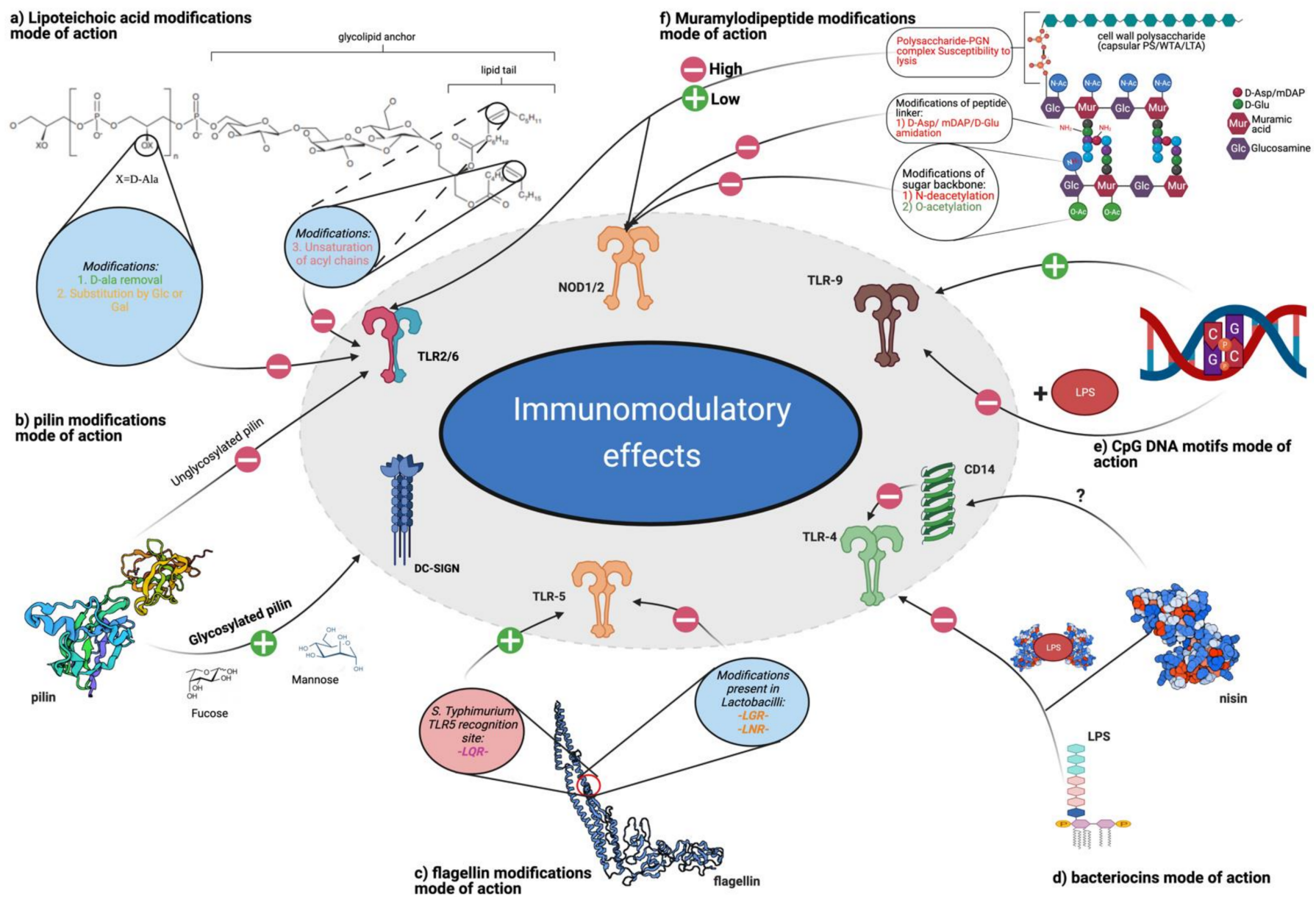

Figure 6. Postbiotic ligands mode of action and their modification, which affects their activity. Plus or minus symbols on arrows symbolize a possible influence on the target receptor; plus = activation/enhanced activation; minus = reduced activation/blockade. (a) Lipoteichoic acid modification: presented structure based on LGG's LTA from [134]. Described modifications mainly influence TLR2 signalling. (b) Pillin modifications: pilin structure based on SpaA pili from LGG (PDB ID: 5f44). (c) Flagellin modifications mode of action: structure based on flagellin from S. thypimuirum (PDB ID: 1ucu) modifications presented in commensal Lactobacilli, reduced activation of the TLR5 receptor. (d) Bacteriocin mode of action: nisin (PDB ID: 5xhb) is presented as an example of bacteriocin with LPS-binding potential, which reduces activation of TLR4. Interaction between CD14 and LL-37 has been reported, lack of similar data for bacterial AMPs. (e) CpG DNA motifs mode of action: presence of inflammatory agent may change $\mathrm{CpG}$ activity from immunostimulatory to anti-inflammatory. (f) Muramyldipeptide modifications mode of action: structure based on review of cell wall structure in LAB strains [335]. Presented modification of sugar backbone lowers lysozyme degradation and NOD1/2 activation. Resistance to lysis of intact cell wall (polysaccharide-peptidoglycan complex) defines immunomodulatory potential. Created with BioRender.com, accessed on 10 October 2021. 


\section{Conclusions}

Postbiotic ligands constitute a big heterogenous group of compounds with different physico-chemical and structural properties. These properties are a result of a long evolutionary adaptation and can be unique to the phylum and/or strain of bacteria. The underlying mechanisms of observed responses are governed both by the structural properties of ligands and their concentration.

Postbiotic ligands interact with host cells via a plethora of routes. These include extracellular (e.g., TLRs, C-lectin) and intracellular (NLRs) pattern recognition receptors. PRRs act in cooperation, adjusting the cellular response to recognized ligands and creating a diverse, strain specific outcome. Furthermore, the effects of particular postbiotic molecules may be dependent on the experimental background, testing conditions and/or disease model. The combination of these factors could create a specific "context of action" by modulating receptor gene expression, ligand sensitivity and immune response, that finally results in a diverse outcome of postbiotic-host interactions.

However our mechanistic knowledge about the whole "cocktail" of molecules present in $\mathrm{HKB} / \mathrm{CFS}$ postbiotic fractions is still far from complete. Currently there are a few already commercially available pharmaceutical preparations based on postbiotics: CFS-like products Colibiogen ${ }^{\circledR}$ (Laves-Arzneimittel GmbH, Schötz, Switzerland), Hylak ${ }^{\circledR}$ Forte (Ratiopharm/Merckle GmbH, Germany) and cell-wall lysate-CytoFlora ${ }^{\circledR}$ (BioRay Inc., Laguna Hills, CA, USA). All are multicomponent and multi strain derived products without a defined exact composition and/or molecular mechanism of action. Further studies on postbiotic-host interactions should focus on defining types of active molecules present in HKB /CFS, their structure-activity relationship (SAR), affinity to multiple PRRs, and finally, their effect on host cells driven by the interplay of PRRs.

Postbiotics not only interact with host cells, they may also exert effects on microbial communities, which is an indirect mechanism of action. Bacteria influence each other's existence through nutrient sharing and/or scavenging and cell-to-cell communications, functioning organizationally like tissues from higher organisms [336,337]. Disruption of the ecological organization of the normal gut microbiota (dysbiosis) can be associated with numerous chronic human disorders. Postbiotics promise to modulate these communities with specific molecules (e.g., bacteriocins, quorum sensing peptides, small organic molecules), influencing the community composition and/or its metabolic profile [338]. Overall, postbiotics are a promising alternative to probiotics/synbiotics and antibiotics, especially for GI tract infections, where restoring microbiome homeostasis is crucial.

From a drug technology point of view, the key advantage of postbiotics lies in their reduced risk of bacteremia [28]. In addition, compared to classical probiotics, postbiotics do not have issues with product shelf survival, and do not require special conditions of storage. Recent findings show that genetic modifications of specific bacterial strains can result in molecules capable of specific functional effects, as seen with single modification of LTA, which dampens or enhances inflammatory reactions.

In summary, postbiotics are a promising source of active molecules with an evolutionary optimized mechanism targeting not only immunological or metabolic systems, but also the microbiome community.

Funding: Foundation for Polish Science: D.G. was supported by POIR.04.04.00-00-3FD3/17 grant within the First TEAM programme of the Foundation for Polish Science co-financed by the European Union under the European Regional Development Fund.; Polish Ministry of Science and Education: R.J. was supported by the Polish Ministry of Science and Education grant no 44/DW/2017/01/1; Polish National Science Centre: PS was supported by the Polish National Science Centre (Grant no. 2020/39/B/ST4/02747).

Institutional Review Board Statement: Not applicable.

Informed Consent Statement: Not applicable.

Conflicts of Interest: The authors declare no conflict of interest. 


\section{References}

1. Tierney, B.T.; Yang, Z.; Luber, J.M.; Beaudin, M.; Wibowo, M.C.; Baek, C.; Mehlenbacher, E.; Patel, C.J.; Kostic, A.D. The Landscape of Genetic Content in the Gut and Oral Human Microbiome. Cell Host. Microbe 2019, 26, 283-295.e8. [CrossRef]

2. Creely, S.J.; McTernan, P.G.; Kusminski, C.M.; Fisher, M.; Da Silva, N.F.; Khanolkar, M.; Evans, M.; Harte, A.L.; Kumar, S. Lipopolysaccharide activates an innate immune system response in human adipose tissue in obesity and type 2 diabetes. Am. J. Physiol. Endocrinol. Metab. 2007, 292, E740-E747. [CrossRef] [PubMed]

3. Corrêa-Oliveira, R.; Fachi, J.L.; Vieira, A.; Sato, F.T.; Vinolo, M.A.R. Regulation of immune cell function by short-chain fatty acids. Clin. Transl. Immunol. 2016, 5, e73. [CrossRef]

4. Cortés-Martín, A.; Selma, M.V.; Tomás-Barberán, F.A.; González-Sarrías, A.; Espín, J.C. Where to Look into the Puzzle of Polyphenols and Health? The Postbiotics and Gut Microbiota Associated with Human Metabotypes. Mol. Nutr. Food Res. 2020, 64, e1900952. [CrossRef] [PubMed]

5. Ostaff, M.J.; Stange, E.F.; Wehkamp, J. Antimicrobial peptides and gut microbiota in homeostasis and pathology: Homeostasis in the gut. EMBO Mol. Med 2013, 5, 1465-1483. [CrossRef]

6. Kubinak, J.L.; Stephens, W.Z.; Soto, R.; Petersen, C.; Chiaro, T.; Gogokhia, L.; Bell, R.; Ajami, N.J.; Petrosino, J.F.; Morrison, L.; et al. MHC variation sculpts individualized microbial communities that control susceptibility to enteric infection. Nat. Commun. 2015, 6, 8642. [CrossRef] [PubMed]

7. Vieira, A.T.; Fukumori, C.; Ferreira, C.M. New insights into therapeutic strategies for gut microbiota modulation in inflammatory diseases. Clin. Transl. Immunol. 2016, 5, e87. [CrossRef]

8. Hill, C.; Guarner, F.; Reid, G.; Gibson, G.R.; Merenstein, D.J.; Pot, B.; Morelli, L.; Canani, R.B.; Flint, H.J.; Salminen, S.; et al. Expert consensus document. The International Scientific Association for Probiotics and Prebiotics consensus statement on the scope and appropriate use of the term probiotic. Nat. Rev. Gastroenterol. Hepatol. 2014, 11, 506-514. [CrossRef] [PubMed]

9. Azad, M.A.K.; Sarker, M.; Wan, D. Immunomodulatory Effects of Probiotics on Cytokine Profiles. Biomed. Res. Int. 2018, 2018, 8063647. [CrossRef] [PubMed]

10. Ganji-Arjenaki, M.; Rafieian-Kopaei, M. Probiotics are a good choice in remission of inflammatory bowel diseases: A meta analysis and systematic review. J. Cell Physiol. 2018, 233, 2091-2103. [CrossRef] [PubMed]

11. Cho, Y.A.; Kim, J. Effect of Probiotics on Blood Lipid Concentrations: A Meta-Analysis of Randomized Controlled Trials. Medicine 2015, 94, e1714. [CrossRef] [PubMed]

12. Park, S.; Bae, J.-H. Probiotics for weight loss: A systematic review and meta-analysis. Nutr. Res. 2015, 35, 566-575. [CrossRef] [PubMed]

13. Qi, D.; Nie, X.-L.; Zhang, J.-J. The effect of probiotics supplementation on blood pressure: A systemic review and meta-analysis. Lipids Health Dis. 2020, 19, 79. [CrossRef]

14. Drago, L. Probiotics and Colon Cancer. Microorganisms 2019, 7, 66. [CrossRef]

15. Akbari, E.; Asemi, Z.; Daneshvar Kakhaki, R.; Bahmani, F.; Kouchaki, E.; Tamtaji, O.R.; Hamidi, G.A.; Salami, M. Effect of Probiotic Supplementation on Cognitive Function and Metabolic Status in Alzheimer's Disease: A Randomized, Double-Blind and Controlled Trial. Front. Aging. Neurosci. 2016, 8, 256. [CrossRef]

16. Li, W.; Guo, J.; Shen, Y.; Huang, L.; Leng, B.; Fan, D.; Shui, L.; Chen, C. Probiotics, prebiotics, and synbiotics for the treatment of dementia: Protocol for a systematic review. Medicine 2020, 99, e18608. [CrossRef]

17. Mishra, V.; Shah, C.; Mokashe, N.; Chavan, R.; Yadav, H.; Prajapati, J. Probiotics as potential antioxidants: A systematic review. J. Agric. Food Chem. 2015, 63, 3615-3626. [CrossRef]

18. Doron, S.; Snydman, D.R. Risk and safety of probiotics. Clin. Infect. Dis. 2015, 60, S129-S134. [CrossRef] [PubMed]

19. Zheng, M.; Zhang, R.; Tian, X.; Zhou, X.; Pan, X.; Wong, A. Assessing the Risk of Probiotic Dietary Supplements in the Context of Antibiotic Resistance. Front. Microbiol. 2017, 8, 908. [CrossRef]

20. Imperial, I.C.V.J.; Ibana, J.A. Addressing the Antibiotic Resistance Problem with Probiotics: Reducing the Risk of Its Double-Edged Sword Effect. Front. Microbiol. 2016, 7, 1983. [CrossRef]

21. Cicenia, A.; Scirocco, A.; Carabotti, M.; Pallotta, L.; Marignani, M.; Severi, C. Postbiotic activities of lactobacilli-derived factors. J. Clin. Gastroenterol. 2014, 48, S18-S22. [CrossRef]

22. Suez, J.; Elinav, E. The path towards microbiome-based metabolite treatment. Nat. Microbiol. 2017, 2, 17075. [CrossRef] [PubMed]

23. Salminen, S.; Collado, M.C.; Endo, A.; Hill, C.; Lebeer, S.; Quigley, E.M.M.; Sanders, M.E.; Shamir, R.; Swann, J.R.; Szajewska, H.; et al. The International Scientific Association of Probiotics and Prebiotics (ISAPP) consensus statement on the definition and scope of postbiotics. Nat. Rev. Gastroenterol. Hepatol. 2021, 18, 1-19. [CrossRef]

24. Taverniti, V.; Guglielmetti, S. The immunomodulatory properties of probiotic microorganisms beyond their viability (ghost probiotics: Proposal of paraprobiotic concept). Genes Nutr. 2011, 6, 261-274. [CrossRef]

25. Aguilar-Toalá, J.E.; Garcia-Varela, R.; Garcia, H.S.; Mata-Haro, V.; González-Córdova, A.F.; Vallejo-Cordoba, B.; Hernán-dezMendoza, A. Postbiotics: An evolving term within the functional foods field. Trends Food Sci. Technol. 2018, 75, 105-114. [CrossRef]

26. Wegh, C.A.M.; Geerlings, S.Y.; Knol, J.; Roeselers, G.; Belzer, C. Postbiotics and Their Potential Applications in Early Life Nutrition and Beyond. Int. J. Mol. Sci. 2019, 20, 4673. [CrossRef]

27. Mayorgas, A.; Dotti, I.; Salas, A. Microbial Metabolites, Postbiotics, and Intestinal Epithelial Function. Mol. Nutr. Food Res. 2021, 65, e2000188. [CrossRef] 
28. Nataraj, B.H.; Ali, S.A.; Behare, P.V.; Yadav, H. Postbiotics-parabiotics: The new horizons in microbial biotherapy and functional foods. Microb. Cell Fact 2020, 19, 168. [CrossRef]

29. Dicks, L.M.T.; Dreyer, L.; Smith, C.; van Staden, A.D. A Review: The Fate of Bacteriocins in the Human Gastro-Intestinal Tract: Do They Cross the Gut-Blood Barrier? Front. Microbiol. 2018, 9, 2297. [CrossRef]

30. Hörmannsperger, G.; von Schillde, M.-A.; Haller, D. Lactocepin as a protective microbial structure in the context of IBD. Gut Microbes 2013, 4, 152-157. [CrossRef]

31. von Schillde, M.-A.; Hörmannsperger, G.; Weiher, M.; Alpert, C.-A.; Hahne, H.; Bäuerl, C.; van Huynegem, K.; Steidler, L.; Hrncir, T.; Pérez-Martínez, G.; et al. Lactocepin secreted by Lactobacillus exerts anti-inflammatory effects by selectively degrading proinflammatory chemokines. Cell Host Microbe 2012, 11, 387-396. [CrossRef]

32. Zhang, L.; Li, N.; Caicedo, R.; Neu, J. Alive and Dead Lactobacillus Rhamnosus GG Decrease Tumor Necrosis Factor-AlphaInduced Interleukin-8 Production in Caco-2 Cells. J. Nutr. 2005, 135, 1752-1756. [CrossRef]

33. Ivanov, D.; Emonet, C.; Foata, F.; Affolter, M.; Delley, M.; Fisseha, M.; Blum-Sperisen, S.; Kochhar, S.; Arigoni, F. A Serpin from the Gut Bacterium Bifidobacterium Longum Inhibits Eukaryotic Elastase-like Serine Proteases. J. Biol. Chem. 2006, 281 , 17246-17252. [CrossRef]

34. Hidalgo-Cantabrana, C.; Moro-García, M.A.; Blanco-Míguez, A.; Fdez-Riverola, F.; Oliván, M.; Royo, L.J.; Riestra, S.; Margolles, A.; Lourenço, A.; Alonso-Arias, R.; et al. The Extracellular Proteins of Lactobacillus Acidophilus DSM 20079T Display AntiInflammatory Effect in Both in Piglets, Healthy Human Donors and Crohn's Disease Patients. J. Funct. Foods 2020, $64,103660$. [CrossRef]

35. Choi, J.H.; Moon, C.M.; Shin, T.-S.; Kim, E.K.; McDowell, A.; Jo, M.-K.; Joo, Y.H.; Kim, S.-E.; Jung, H.-K.; Shim, K.-N.; et al. Lactobacillus Paracasei-Derived Extracellular Vesicles Attenuate the Intestinal Inflammatory Response by Augmenting the Endoplasmic Reticulum Stress Pathway. Exp. Mol. Med. 2020, 52, 423-437. [CrossRef]

36. Patil, S.; Sawant, S.; Hauff, K.; Hampp, G. Validated Postbiotic Screening Confirms Presence of Physiologically-Active Metabolites, Such as Short-Chain Fatty Acids, Amino Acids and Vitamins in Hylak ${ }^{\circledR}$ Forte. Probiotics Antimicrob. Proteins 2019, 11, 1124-1131. [CrossRef]

37. Ewaschuk, J.B.; Walker, J.W.; Diaz, H.; Madsen, K.L. Bioproduction of Conjugated Linoleic Acid by Probiotic Bacteria Occurs in Vitro and in Vivo in Mice. J. Nutr. 2006, 136, 1483-1487. [CrossRef]

38. Kepert, I.; Fonseca, J.; Müller, C.; Milger, K.; Hochwind, K.; Kostric, M.; Fedoseeva, M.; Ohnmacht, C.; Dehmel, S.; Nathan, P.; et al. D-Tryptophan from Probiotic Bacteria Influences the Gut Microbiome and Allergic Airway Disease. J. Allergy Clin. Immunol. 2017, 139, 1525-1535. [CrossRef]

39. Venkatesh, M.; Mukherjee, S.; Wang, H.; Li, H.; Sun, K.; Benechet, A.P.; Qiu, Z.; Maher, L.; Redinbo, M.R.; Phillips, R.S.; et al. Symbiotic Bacterial Metabolites Regulate Gastrointestinal Barrier Function via the Xenobiotic Sensor PXR and Toll-like Receptor 4. Immunity 2014, 41, 296-310. [CrossRef]

40. Ehrlich, A.M.; Henrick, B.; Pacheco, A.; Taft, D.; Xu, G.; Huda, N.; Lozada-Contreras, M.; Goodson, M.; Slupsky, C.; Mills, D.; et al. Bifidobacterium Grown on Human Milk Oligosaccharides Produce Tryptophan Metabolite Indole-3-Lactic Acid That Significantly Decreases Inflammation in Intestinal Cells in Vitro. FASEB J. 2018, 32, lb359. [CrossRef]

41. Segawa, S.; Fujiya, M.; Konishi, H.; Ueno, N.; Kobayashi, N.; Shigyo, T.; Kohgo, Y. Probiotic-Derived Polyphosphate Enhances the Epithelial Barrier Function and Maintains Intestinal Homeostasis through Integrin-p38 MAPK Pathway. PLoS ONE 2011, 6, e23278. [CrossRef]

42. Feng, G.; Feng, Y.; Guo, T.; Yang, Y.; Guo, W.; Huang, M.; Wu, H.; Zeng, M. Biogenic Polyphosphate Nanoparticles from Synechococcus Sp. PCC 7002 Exhibit Intestinal Protective Potential in Human Intestinal Epithelial Cells In Vitro and Murine Small Intestine Ex Vivo. J. Agric. Food Chem. 2018, 66, 8026-8035. [CrossRef]

43. Kato-Mori, Y.; Orihashi, T.; Kanai, Y.; Sato, M.; Sera, K.; Hagiwara, K. Fermentation Metabolites from Lactobacillus Gasseri and Propionibacterium Freudenreichii Exert Bacteriocidal Effects in Mice. J. Med. Food 2010, 13, 1460-1467. [CrossRef]

44. Johnson, B.; Selle, K.; O’Flaherty, S.; Goh, Y.J.; Klaenhammer, T. Identification of Extracellular Surface-Layer Associated Proteins in Lactobacillus Acidophilus NCFM. Microbiology 2013, 159, 2269-2282. [CrossRef]

45. Taverniti, V.; Stuknyte, M.; Minuzzo, M.; Arioli, S.; De Noni, I.; Scabiosi, C.; Cordova, Z.M.; Junttila, I.; Hämäläinen, S.; Turpeinen, H.; et al. S-Layer Protein Mediates the Stimulatory Effect of Lactobacillus Helveticus MIMLh5 on Innate Immunity. Appl. Environ. Microbiol. 2013, 79, 1221-1231. [CrossRef]

46. Prado Acosta, M.; Ruzal, S.M.; Cordo, S.M. S-Layer Proteins from Lactobacillus Sp. Inhibit Bacterial Infection by Blockage of DC-SIGN Cell Receptor. Int. J. Biol. Macromol. 2016, 92, 998-1005. [CrossRef]

47. Prado Acosta, M.; Geoghegan, E.M.; Lepenies, B.; Ruzal, S.; Kielian, M.; Martinez, M.G. Surface (S) Layer Proteins of Lactobacillus Acidophilus Block Virus Infection via DC-SIGN Interaction. Front. Microbiol. 2019, 10, 810. [CrossRef]

48. Kobatake, E.; Kabuki, T. S-Layer Protein of Lactobacillus Helveticus SBT2171 Promotes Human $\beta$-Defensin 2 Expression via TLR2-JNK Signaling. Front. Microbiol. 2019, 10, 2414. [CrossRef]

49. Lebeer, S.; Claes, I.J.J.; Vanderleyden, J. Anti-Inflammatory Potential of Probiotics: Lipoteichoic Acid Makes a Difference. Trends Microbiol. 2012, 20, 5-10. [CrossRef]

50. Macho Fernandez, E.; Valenti, V.; Rockel, C.; Hermann, C.; Pot, B.; Boneca, I.G.; Grangette, C. Anti-Inflammatory Capacity of Selected Lactobacilli in Experimental Colitis Is Driven by NOD2-Mediated Recognition of a Specific Peptidoglycan-Derived Muropeptide. Gut 2011, 60, 1050-1059. [CrossRef] [PubMed] 
51. Xu, X.; Qiao, Y.; Peng, Q.; Shi, B.; Dia, V.P. Antioxidant and Immunomodulatory Properties of Partially Purified Exopolysaccharide from Lactobacillus Casei Isolated from Chinese Northeast Sauerkraut. Immunol. Investig. 2021, 1-18. [CrossRef]

52. Górska, S.; Hermanova, P.; Ciekot, J.; Schwarzer, M.; Srutkova, D.; Brzozowska, E.; Kozakova, H.; Gamian, A. Chemical Characterization and Immunomodulatory Properties of Polysaccharides Isolated from Probiotic Lactobacillus Casei LOCK 0919. Glycobiology 2017, 27, 275-277.

53. Fanning, S.; Hall, L.J.; van Sinderen, D. Bifidobacterium Breve UCC2003 Surface Exopolysaccharide Production Is a Beneficial Trait Mediating Commensal-Host Interaction through Immune Modulation and Pathogen Protection. Gut Microbes 2012, 3, 420-425. [CrossRef]

54. Górska, S.; Schwarzer, M.; Jachymek, W.; Srutkova, D.; Brzozowska, E.; Kozakova, H.; Gamian, A. Distinct Immunomodulation of Bone Marrow-Derived Dendritic Cell Responses to Lactobacillus Plantarum WCFS1 by Two Different Polysaccharides Isolated from Lactobacillus Rhamnosus LOCK 0900. Appl. Environ. Microbiol. 2014, 80, 6506-6516. [CrossRef]

55. Ai, L.; Zhang, H.; Guo, B.; Chen, W.; Wu, Z.; Wu, Y. Preparation, Partial Characterization and Bioactivity of Exopolysaccharides from Lactobacillus Casei LC2W. Carbohydr. Polym. 2008, 74, 353-357. [CrossRef]

56. Gao, K.; Wang, C.; Liu, L.; Dou, X.; Liu, J.; Yuan, L.; Zhang, W.; Wang, H. Immunomodulation and Signaling Mechanism of Lactobacillus Rhamnosus GG and Its Components on Porcine Intestinal Epithelial Cells Stimulated by Lipopolysaccharide. J. Microbiol. Immunol. Infect. 2017, 50, 700-713. [CrossRef]

57. Zhang, Z.; Zhou, Z.; Li, Y.; Zhou, L.; Ding, Q.; Xu, L. Isolated Exopolysaccharides from Lactobacillus Rhamnosus GG Alleviated Adipogenesis Mediated by TLR2 in Mice. Sci. Rep. 2016, 6, 36083. [CrossRef]

58. Agostoni, C.; Goulet, O.; Kolacek, S.; Koletzko, B.; Moreno, L.; Puntis, J.; Rigo, J.; Shamir, R.; Szajewska, H.; Turck, D. Fermented Infant Formulae Without Live Bacteria. J. Pediatr. Gastroenterol. Nutr. 2007, 44, 392-397. [CrossRef]

59. Szajewska, H.; Skórka, A.; Pieścik-Lech, M. Fermented Infant Formulas without Live Bacteria: A Systematic Review. Eur. J. Pediatr. 2015, 174, 1413-1420. [CrossRef]

60. Jeong, K.; Kim, M.; Jeon, S.A.; Kim, Y.-H.; Lee, S. A Randomized Trial of Lactobacillus Rhamnosus IDCC 3201 Tyndallizate (RHT3201) for Treating Atopic Dermatitis. Pediatr. Allergy Immunol. 2020. [CrossRef]

61. Vinolo, M.A.R.; Rodrigues, H.G.; Nachbar, R.T.; Curi, R. Regulation of Inflammation by Short Chain Fatty Acids. Nutrients 2011, 3, 858-876. [CrossRef]

62. Sun, M.; Wu, W.; Chen, L.; Yang, W.; Huang, X.; Ma, C.; Chen, F.; Xiao, Y.; Zhao, Y.; Ma, C.; et al. Microbiota-Derived Short-Chain Fatty Acids Promote Th1 Cell IL-10 Production to Maintain Intestinal Homeostasis. Nat. Commun. 2018, 9, 3555. [CrossRef]

63. McDaniel, D.K.; Eden, K.; Ringel, V.M.; Allen, I.C. Emerging Roles for Noncanonical NF-кB Signaling in the Modulation of Inflammatory Bowel Disease Pathobiology. Inflamm. Bowel Dis. 2016, 22, 2265-2279. [CrossRef]

64. Kim, E.K.; Choi, E.-J. Pathological Roles of MAPK Signaling Pathways in Human Diseases. Biochim. Biophys. Acta 2010, 1802, 396-405. [CrossRef] [PubMed]

65. Atreya, I.; Atreya, R.; Neurath, M.F. NF-кB in Inflammatory Bowel Disease. J. Intern. Med. 2008, 263, 591-596. [CrossRef]

66. Broom, O.J.; Widjaya, B.; Troelsen, J.; Olsen, J.; Nielsen, O.H. Mitogen Activated Protein Kinases: A Role in Inflammatory Bowel Disease? Clin. Exp. Immunol. 2009, 158, 272-280. [CrossRef]

67. Schulze-Osthoff, K.; Ferrari, D.; Riehemann, K.; Wesselborg, S. Regulation of NF-Kappa B Activation by MAP Kinase Cascades. Immunobiology 1997, 198, 35-49. [CrossRef]

68. Shi, J.-H.; Sun, S.-C. Tumor Necrosis Factor Receptor-Associated Factor Regulation of Nuclear Factor $\kappa$ B and Mitogen-Activated Protein Kinase Pathways. Front. Immunol. 2018, 9, 1849. [CrossRef] [PubMed]

69. Kitazawa, H.; Villena, J.; Alvarez, S. Probiotics: Immunobiotics and Immunogenics; CRC Press: Boca Raton, FL, USA, 2013; ISBN 9781482206852.

70. Virginia Rodriguez, A.; Griet, M. NF-кB in Anti-Inflammatory Activity of Probiotics: An Update. Curr. Immunol. Rev. 2017, 12, 74-82. [CrossRef]

71. Wang, H.; Li, S.; Li, H.; Du, F.; Guan, J.; Wu, Y. Mechanism of Probiotic VSL\#3 Inhibiting NF-kB and TNF- $\alpha$ on Colitis through TLR4-NF-кB Signal Pathway. Iran. J. Public Health 2019, 48, 1292-1300.

72. Plaza-Díaz, J.; Ruiz-Ojeda, F.J.; Vilchez-Padial, L.M.; Gil, A. Evidence of the Anti-Inflammatory Effects of Probiotics and Synbiotics in Intestinal Chronic Diseases. Nutrients 2017, 9, 555. [CrossRef] [PubMed]

73. Taniguchi, K.; Karin, M. NF-кB, Inflammation, Immunity and Cancer: Coming of Age. Nat. Rev. Immunol. 2018, 18, 309-324. [CrossRef] [PubMed]

74. Oeckinghaus, A.; Ghosh, S. The NF-kappaB Family of Transcription Factors and Its Regulation. Cold Spring Harb. Perspect. Biol. 2009, 1, a000034. [CrossRef]

75. Giuliani, C.; Bucci, I.; Napolitano, G. The Role of the Transcription Factor Nuclear Factor-Kappa B in Thyroid Autoimmunity and Cancer. Front. Endocrinol. 2018, 9, 471. [CrossRef]

76. Dong, C.; Davis, R.J.; Flavell, R.A. MAP Kinases in the Immune Response. Annu. Rev. Immunol. 2002, 20, 55-72. [CrossRef] [PubMed]

77. Zhang, Y.; Dong, C. Regulatory Mechanisms of Mitogen-Activated Kinase Signaling. Cell. Mol. Life Sci. 2007, 64, 2771-2789. [CrossRef] 
78. Houde, M.; Laprise, P.; Jean, D.; Blais, M.; Asselin, C.; Rivard, N. Intestinal Epithelial Cell Differentiation Involves Activation of p38 Mitogen-Activated Protein Kinase That Regulates the Homeobox Transcription Factor CDX2. J. Biol. Chem. 2001, 276, 21885-21894. [CrossRef] [PubMed]

79. Wakeman, D.; Schneider, J.E.; Liu, J.; Wandu, W.S.; Erwin, C.R.; Guo, J.; Stappenbeck, T.S.; Warner, B.W. Deletion of p38-Alpha Mitogen-Activated Protein Kinase within the Intestinal Epithelium Promotes Colon Tumorigenesis. Surgery 2012, 152, 286-293. [CrossRef]

80. Morrison, D.K. MAP Kinase Pathways. Cold Spring Harb. Perspect. Biol. 2012, 4. [CrossRef]

81. Cargnello, M.; Roux, P.P. Activation and Function of the MAPKs and Their Substrates, the MAPK-Activated Protein Kinases. Microbiol. Mol. Biol. Rev. 2011, 75, 50-83. [CrossRef]

82. Lee, S.; Rauch, J.; Kolch, W. Targeting MAPK Signaling in Cancer: Mechanisms of Drug Resistance and Sensitivity. Int. J. Mol. Sci. 2020, 21, 1102. [CrossRef]

83. Jones, S.E.; Versalovic, J. Probiotic Lactobacillus Reuteri Biofilms Produce Antimicrobial and Anti-Inflammatory Factors. BMC Microbiol. 2009, 9, 35. [CrossRef] [PubMed]

84. Ashraf, R.; Vasiljevic, T.; Smith, S.C.; Donkor, O.N. Effect of Cell-Surface Components and Metabolites of Lactic Acid Bacteria and Probiotic Organisms on Cytokine Production and Induction of CD25 Expression in Human Peripheral Mononuclear Cells. J. Dairy Sci. 2014, 97, 2542-2558. [CrossRef] [PubMed]

85. Uchinaka, A.; Azuma, N.; Mizumoto, H.; Nakano, S.; Minamiya, M.; Yoneda, M.; Aoyama, K.; Komatsu, Y.; Yamada, Y.; Murohara, T.; et al. Anti-Inflammatory Effects of Heat-Killed Lactobacillus Plantarum L-137 on Cardiac and Adipose Tissue in Rats with Metabolic Syndrome. Sci. Rep. 2018, 8, 8156. [CrossRef]

86. De Marco, S.; Sichetti, M.; Muradyan, D.; Piccioni, M.; Traina, G.; Pagiotti, R.; Pietrella, D. Probiotic Cell-Free Supernatants Exhibited Anti-Inflammatory and Antioxidant Activity on Human Gut Epithelial Cells and Macrophages Stimulated with LPS. Evid. Based. Complement. Alternat. Med. 2018, 2018, 1756308. [CrossRef]

87. Lakhdari, O.; Tap, J.; Béguet-Crespel, F.; Le Roux, K.; de Wouters, T.; Cultrone, A.; Nepelska, M.; Lefèvre, F.; Doré, J.; Blottière, H.M. Identification of NF-кB Modulation Capabilities within Human Intestinal Commensal Bacteria. J. Biomed. Biotechnol. 2011, 2011, 282356. [CrossRef]

88. Imaoka, A.; Shima, T.; Kato, K.; Mizuno, S.; Uehara, T.; Matsumoto, S.; Setoyama, H.; Hara, T.; Umesaki, Y. Anti-Inflammatory Activity of Probiotic Bifidobacterium: Enhancement of IL-10 Production in Peripheral Blood Mononuclear Cells from Ulcerative Colitis Patients and Inhibition of IL-8 Secretion in HT-29 Cells. World J. Gastroenterol. 2008, 14, 2511-2516. [CrossRef]

89. Petrof, E.O.; Kojima, K.; Ropeleski, M.J.; Musch, M.W.; Tao, Y.; De Simone, C.; Chang, E.B. Probiotics Inhibit Nuclear FactorkappaB and Induce Heat Shock Proteins in Colonic Epithelial Cells through Proteasome Inhibition. Gastroenterology 2004, 127, 1474-1487. [CrossRef]

90. Heuvelin, E.; Lebreton, C.; Grangette, C.; Pot, B.; Cerf-Bensussan, N.; Heyman, M. Mechanisms Involved in Alleviation of Intestinal Inflammation by Bifidobacterium Breve Soluble Factors. PLoS ONE 2009, 4, e5184. [CrossRef] [PubMed]

91. Kaci, G.; Lakhdari, O.; Doré, J.; Dusko Ehrlich, S.; Renault, P.; Blottière, H.M.; Delorme, C. Inhibition of the NF-kB Pathway in Human Intestinal Epithelial Cells by Commensal Streptococcus Salivarius. Appl. Environ. Microbiol. 2011, 77, 4681-4684. [CrossRef]

92. Wang, Z.; Wang, J.; Cheng, Y.; Liu, X.; Huang, Y. Secreted Factors from Bifidobacterium Animalis Subsp. Lactis Inhibit NF-kBMediated Interleukin-8 Gene Expression in Caco-2 Cells. Appl. Environ. Microbiol. 2011, 77, 8171-8174. [CrossRef] [PubMed]

93. Petrof, E.O.; Claud, E.C.; Sun, J.; Abramova, T.; Guo, Y.; Waypa, T.S.; He, S.-M.; Nakagawa, Y.; Chang, E.B. Bacteria-Free Solution Derived from Lactobacillus Plantarum Inhibits Multiple NF-kappaB Pathways and Inhibits Proteasome Function. Inflamm. Bowel Dis. 2009, 15, 1537-1547. [CrossRef]

94. Ismaeil, H.; Abdo, W.; Amer, S.; Tahoun, A.; Massoud, D.; Zanaty, E.; Bin-Jumah, M.; Mahmoud, A.M. Ameliorative Effect of Heat-Killed Lactobacillus Plantarum L.137 And/or Aloe Vera against Colitis in Mice. Processes 2020, 8, 225. [CrossRef]

95. Bermudez-Brito, M.; Muñoz-Quezada, S.; Gomez-Llorente, C.; Romero, F.; Gil, A. Lactobacillus Rhamnosus and Its Cell-Free Culture Supernatant Differentially Modulate Inflammatory Biomarkers in Escherichia Coli-Challenged Human Dendritic Cells. Br. J. Nutr. 2014, 111, 1727-1737. [CrossRef] [PubMed]

96. Chon, H.; Choi, B.; Jeong, G.; Lee, E.; Lee, S. Suppression of Proinflammatory Cytokine Production by Specific Metabolites of Lactobacillus Plantarum 10hk2 via Inhibiting NF-кB and p38 MAPK Expressions. Comp. Immunol. Microbiol. Infect. Dis. 2010, 33, e41-e49. [CrossRef]

97. Ghadimi, D.; de Vrese, M.; Heller, K.J.; Schrezenmeir, J. Effect of Natural Commensal-Origin DNA on Toll-like Receptor 9 (TLR9) Signaling Cascade, Chemokine IL-8 Expression, and Barrier Integritiy of Polarized Intestinal Epithelial Cells. Inflamm. Bowel Dis. 2010, 16, 410-427. [CrossRef] [PubMed]

98. Yu, H.-S.; Lee, N.-K.; Choi, A.-J.; Choe, J.-S.; Bae, C.H.; Paik, H.-D. Anti-Inflammatory Potential of Probiotic Strain Weissella Cibaria JW15 Isolated from Kimchi through Regulation of NF-kB and MAPKs Pathways in LPS-Induced RAW 264.7 Cells. J. Microbiol. Biotechnol. 2019, 29, 1022-1032. [CrossRef]

99. Jung, J.-I.; Baek, S.-M.; Nguyen, T.H.; Kim, J.W.; Kang, C.-H.; Kim, S.; Imm, J.-Y. Effects of Probiotic Culture Supernatant on Cariogenic Biofilm Formation and RANKL-Induced Osteoclastogenesis in RAW 264.7 Macrophages. Molecules 2021, $26,733$. [CrossRef] 
100. Rocha-Ramírez, L.M.; Pérez-Solano, R.A.; Castañón-Alonso, S.L.; Moreno Guerrero, S.S.; Ramírez Pacheco, A.; García Garibay, M.; Eslava, C. Probiotic Lactobacillus Strains Stimulate the Inflammatory Response and Activate Human Macrophages. J. Immunol. Res. 2017, 2017, 4607491. [CrossRef]

101. Karlsson, M.; Scherbak, N.; Reid, G.; Jass, J. Lactobacillus Rhamnosus GR-1 Enhances NF-kappaB Activation in Escherichia Coli-Stimulated Urinary Bladder Cells through TLR4. BMC Microbiol. 2012, 12, 15. [CrossRef]

102. Tao, Y.; Drabik, K.A.; Waypa, T.S.; Musch, M.W.; Alverdy, J.C.; Schneewind, O.; Chang, E.B.; Petrof, E.O. Soluble Factors from Lactobacillus GG Activate MAPKs and Induce Cytoprotective Heat Shock Proteins in Intestinal Epithelial Cells. Am. J. Physiol. Cell Physiol. 2006, 290, C1018-C1030. [CrossRef]

103. Fujiya, M.; Musch, M.W.; Nakagawa, Y.; Hu, S.; Alverdy, J.; Kohgo, Y.; Schneewind, O.; Jabri, B.; Chang, E.B. The Bacillus Subtilis Quorum-Sensing Molecule CSF Contributes to Intestinal Homeostasis via OCTN2, a Host Cell Membrane Transporter. Cell Host Microbe 2007, 1, 299-308. [CrossRef]

104. Schlee, M.; Harder, J.; Köten, B.; Stange, E.F.; Wehkamp, J.; Fellermann, K. Probiotic Lactobacilli and VSL\# 3 Induce Enterocyte ß-Defensin 2. Clin. Exp. Immunol. 2008, 151, 528-535.

105. Bidmon-Fliegenschnee, B.; Lederhuber, H.C.; Csaicsich, D.; Pichler, J.; Herzog, R.; Memaran-Dadgar, N.; Huber, W.-D.; Aufricht, C.; Kratochwill, K. Overexpression of Hsp70 Confers Cytoprotection during Gliadin Exposure in Caco-2 Cells. Pediatr. Res. 2015, 78, 358-364. [CrossRef]

106. Koeninger, L.; Armbruster, N.S.; Brinch, K.S.; Kjaerulf, S.; Andersen, B.; Langnau, C.; Autenrieth, S.E.; Schneidawind, D.; Stange, E.F.; Malek, N.P.; et al. Human $\beta$-Defensin 2 Mediated Immune Modulation as Treatment for Experimental Colitis. Front. Immunol. 2020, 11, 93. [CrossRef] [PubMed]

107. Iyer, C.; Kosters, A.; Sethi, G.; Kunnumakkara, A.B.; Aggarwal, B.B.; Versalovic, J. Probiotic Lactobacillus Reuteri Promotes TNF-Induced Apoptosis in Human Myeloid Leukemia-Derived Cells by Modulation of NF-кB and MAPK Signalling. Cell. Microbiol. 2008, 10, 1442-1452. [CrossRef] [PubMed]

108. Jeong, M.; Kim, J.H.; Yang, H.; Kang, S.D.; Song, S.; Lee, D.; Lee, J.S.; Yoon Park, J.H.; Byun, S.; Lee, K.W. Heat-Killed Lactobacillus Plantarum KCTC 13314BP Enhances Phagocytic Activity and Immunomodulatory Effects Via Activation of MAPK and STAT3 Pathways. J. Microbiol. Biotechnol. 2019, 29, 1248-1254. [CrossRef] [PubMed]

109. Li, L.; Jiang, Y.-J.; Yang, X.-Y.; Liu, Y.; Wang, J.-Y.; Man, C.-X. Immunoregulatory Effects on Caco-2 Cells and Mice of Exopolysaccharides Isolated from Lactobacillus Acidophilus NCFM. Food Funct. 2014, 5, 3261-3268. [CrossRef]

110. Wang, H.; Cheng, X.; Zhang, L.; Xu, S.; Zhang, Q.; Lu, R. A Surface-Layer Protein from Lactobacillus Acidophilus NCFM Induces Autophagic Death in HCT116 Cells Requiring ROS-Mediated Modulation of mTOR and JNK Signaling Pathways. Food Funct. 2019, 10, 4102-4112. [CrossRef]

111. Wang, H.; Zhang, L.; Xu, S.; Pan, J.; Zhang, Q.; Lu, R. Surface-Layer Protein from Lactobacillus Acidophilus NCFM Inhibits Lipopolysaccharide-Induced Inflammation through MAPK and NF-кB Signaling Pathways in RAW264.7 Cells. J. Agric. Food Chem. 2018, 66, 7655-7662. [CrossRef]

112. Liu, Q.; Yu, Z.; Tian, F.; Zhao, J.; Zhang, H.; Zhai, Q.; Chen, W. Surface Components and Metabolites of Probiotics for Regulation of Intestinal Epithelial Barrier. Microb. Cell Fact. 2020, 19, 23. [CrossRef] [PubMed]

113. Wagner, C.E.; Wheeler, K.M.; Ribbeck, K. Mucins and Their Role in Shaping the Functions of Mucus Barriers. Annu. Rev. Cell Dev. Biol. 2018, 34, 189-215. [CrossRef]

114. Osaki, M.; Oshimura, M.; Ito, H. PI3K-Akt Pathway: Its Functions and Alterations in Human Cancer. Apoptosis 2004, 9, 667-676. [CrossRef]

115. Schultze, S.M.; Hemmings, B.A.; Niessen, M.; Tschopp, O. PI3K/AKT, MAPK and AMPK Signalling: Protein Kinases in Glucose Homeostasis. Expert Rev. Mol. Med. 2012, 14, e1. [CrossRef]

116. Paveljšek, D.; Ivičak-Kocjan, K.; Treven, P.; Benčina, M.; Jerala, R.; Rogelj, I. Distinctive Probiotic Features Share Common TLR2-Dependent Signalling in Intestinal Epithelial Cells. Cell. Microbiol. 2021, 23, e13264. [CrossRef] [PubMed]

117. Mohseni, A.H.; Casolaro, V.; Bermúdez-Humarán, L.G.; Keyvani, H.; Taghinezhad-S, S. Modulation of the PI3K/Akt/mTOR Signaling Pathway by Probiotics as a Fruitful Target for Orchestrating the Immune Response. Gut Microbes 2021, 13 , 1-17. [CrossRef]

118. Zhang, M.; Wang, C.; Wang, C.; Zhao, H.; Zhao, C.; Chen, Y.; Wang, Y.; McClain, C.; Feng, W. Enhanced AMPK Phosphorylation Contributes to the Beneficial Effects of Lactobacillus Rhamnosus GG Supernatant on Chronic-Alcohol-Induced Fatty Liver Disease. J. Nutr. Biochem. 2015, 26, 337-344. [CrossRef]

119. Lew, L.C.; Hor, Y.Y.; Jaafar, M.H.; Lau, A.S.Y.; Ong, J.S.; Chuah, L.O.; Yap, K.P.; Azzam, G.; Azlan, A.; Liong, M.T. Lactobacilli Modulated AMPK Activity and Prevented Telomere Shortening in Ageing Rats. Benef. Microbes 2019, 10, 883-892. [CrossRef]

120. Ventura-Sobrevilla, J.M.; Boone-Villa, V.D.; Jiménez-Villarreal, J.; Nevarez-Moorillón, G.V. Influence of Probiotics Over AMPKDependent Health Activity: A Look into Its Molecular Mechanisms. In Advances in Probiotics for Sustainable Food and Medicine; Goel, G., Kumar, A., Eds.; Springer Singapore: Singapore, 2021; pp. 213-223. ISBN 9789811567957.

121. Yan, F.; Polk, D.B. Probiotic Bacterium Prevents Cytokine-Induced Apoptosis in Intestinal Epithelial Cells. J. Biol. Chem. 2002, 277, 50959-50965. [CrossRef]

122. Yan, F.; Cao, H.; Cover, T.L.; Whitehead, R.; Washington, M.K.; Polk, D.B. Soluble Proteins Produced by Probiotic Bacteria Regulate Intestinal Epithelial Cell Survival and Growth. Gastroenterology 2007, 132, 562-575. [CrossRef] 
123. Ammoscato, F.; Scirocco, A.; Altomare, A.; Matarrese, P.; Petitta, C.; Ascione, B.; Caronna, R.; Guarino, M.; Marignani, M.; Cicala, M.; et al. Lactobacillus Rhamnosus Protects Human Colonic Muscle from Pathogen Lipopolysaccharide-Induced Damage. Neurogastroenterol. Motil. 2013, 25, 984-e777. [CrossRef]

124. Caballero-Franco, C.; Keller, K.; De Simone, C.; Chadee, K. The VSL\#3 Probiotic Formula Induces Mucin Gene Expression and Secretion in Colonic Epithelial Cells. Am. J. Physiol.-Gastrointest. Liver Physiol. 2007, 292, G315-G322.

125. Gao, J.; Li, Y.; Wan, Y.; Hu, T.; Liu, L.; Yang, S.; Gong, Z.; Zeng, Q.; Wei, Y.; Yang, W.; et al. A Novel Postbiotic From Lactobacillus Rhamnosus GG With a Beneficial Effect on Intestinal Barrier Function. Front. Microbiol. 2019, 10, 477. [CrossRef] [PubMed]

126. Yan, H.; Ajuwon, K.M. Butyrate Modifies Intestinal Barrier Function in IPEC-J2 Cells through a Selective Upregulation of Tight Junction Proteins and Activation of the Akt Signaling Pathway. PLoS ONE 2017, 12, e0179586. [CrossRef] [PubMed]

127. Izuddin, W.I.; Loh, T.C.; Foo, H.L.; Samsudin, A.A.; Humam, A.M. Postbiotic L. Plantarum RG14 Improves Ruminal Epithelium Growth, Immune Status and Upregulates the Intestinal Barrier Function in Post-Weaning Lambs. Sci. Rep. 2019,9 , 9938.

128. Han, N.; Jia, L.; Su, Y.; Du, J.; Guo, L.; Luo, Z.; Liu, Y. Lactobacillus Reuteri Extracts Promoted Wound Healing via PI3K/AKT/ $\beta$ catenin/TGF $\beta 1$ Pathway. Stem Cell Res. Ther. 2019, 10, 243. [CrossRef] [PubMed]

129. Kumar, R.; Sharma, A.; Gupta, M.; Padwad, Y.; Sharma, R. Cell-Free Culture Supernatant of Probiotic Lactobacillus Fermentum Protects Against H2O2-Induced Premature Senescence by Suppressing ROS-Akt-mTOR Axis in Murine Preadipocytes. Probiotics Antimicrob. Proteins 2020, 12, 563-576. [CrossRef]

130. Takeuchi, O.; Akira, S. Pattern Recognition Receptors and Inflammation. Cell 2010, 140, 805-820. [CrossRef]

131. Kawai, T.; Akira, S. The Role of Pattern-Recognition Receptors in Innate Immunity: Update on Toll-like Receptors. Nat. Immunol. 2010, 11, 373-384. [CrossRef]

132. Franchi, L.; Warner, N.; Viani, K. Function of Nod-like Receptors in Microbial Recognition and Host Defense. Immunol. Rev. 2009, 227, 106-128. [CrossRef] [PubMed]

133. Geijtenbeek, T.B.H.; Gringhuis, S.I. Signalling through C-Type Lectin Receptors: Shaping Immune Responses. Nat. Rev. Immunol. 2009, 9, 465-479. [CrossRef]

134. Lebeer, S.; Vanderleyden, J.; De Keersmaecker, S.C.J. Host Interactions of Probiotic Bacterial Surface Molecules: Comparison with Commensals and Pathogens. Nat. Rev. Microbiol. 2010, 8, 171-184. [CrossRef]

135. Rakoff-Nahoum, S.; Paglino, J.; Eslami-Varzaneh, F.; Edberg, S.; Medzhitov, R. Recognition of Commensal Microflora by Toll-like Receptors Is Required for Intestinal Homeostasis. Cell 2004, 118, 229-241. [CrossRef]

136. Lee, J.; Mo, J.-H.; Katakura, K.; Alkalay, I.; Rucker, A.N.; Liu, Y.-T.; Lee, H.-K.; Shen, C.; Cojocaru, G.; Shenouda, S.; et al. Maintenance of Colonic Homeostasis by Distinctive Apical TLR9 Signalling in Intestinal Epithelial Cells. Nat. Cell Biol. 2006, 8, 1327-1336. [CrossRef] [PubMed]

137. Bermudez-Brito, M.; Plaza-Díaz, J.; Muñoz-Quezada, S.; Gómez-Llorente, C.; Gil, A. Probiotic Mechanisms of Action. Ann. Nutr. Metab. 2012, 61, 160-174. [CrossRef] [PubMed]

138. Abreu, M.T.; Fukata, M.; Arditi, M. TLR Signaling in the Gut in Health and Disease. J. Immunol. 2005, 174, 4453-4460. [CrossRef]

139. Bell, J.K.; Mullen, G.E.D.; Leifer, C.A.; Mazzoni, A.; Davies, D.R.; Segal, D.M. Leucine-Rich Repeats and Pathogen Recognition in Toll-like Receptors. Trends Immunol. 2003, 24, 528-533. [CrossRef]

140. Gao, W.; Xiong, Y.; Li, Q.; Yang, H. Inhibition of Toll-Like Receptor Signaling as a Promising Therapy for Inflammatory Diseases: A Journey from Molecular to Nano Therapeutics. Front. Physiol. 2017, 8, 508. [CrossRef]

141. Rosenfeld, Y.; Shai, Y. Lipopolysaccharide (Endotoxin)-Host Defense Antibacterial Peptides Interactions: Role in Bacterial Resistance and Prevention of Sepsis. Biochim. Biophys. Acta 2006, 1758, 1513-1522. [CrossRef]

142. Kawasaki, T.; Kawai, T. Toll-like Receptor Signaling Pathways. Front. Immunol. 2014, 5, 461. [CrossRef]

143. Xu, Y.; Tao, X.; Shen, B.; Horng, T.; Medzhitov, R.; Manley, J.L.; Tong, L. Structural Basis for Signal Transduction by the Toll/interleukin-1 Receptor Domains. Nature 2000, 408, 111-115. [CrossRef]

144. Dunne, A.; Ejdebäck, M.; Ludidi, P.L.; O’Neill, L.A.J.; Gay, N.J. Structural Complementarity of Toll/Interleukin-1 Receptor Domains in Toll-like Receptors and the Adaptors Mal and MyD88. J. Biol. Chem. 2003, 278, 41443-41451. [CrossRef]

145. Miguel, R.N.; Wong, J.; Westoll, J.F.; Brooks, H.J.; O’Neill, L.A.J.; Gay, N.J.; Bryant, C.E.; Monie, T.P. A Dimer of the Toll-Like Receptor 4 Cytoplasmic Domain Provides a Specific Scaffold for the Recruitment of Signalling Adaptor Proteins. PLoS ONE 2007, 2, e788.

146. Deguine, J.; Barton, G.M. MyD88: A Central Player in Innate Immune Signaling. F1000Prime Rep. 2014, 6, 97. [CrossRef] [PubMed]

147. Wang, C.; Chen, T.; Zhang, J.; Yang, M.; Li, N.; Xu, X.; Cao, X. The E3 Ubiquitin Ligase Nrdp1'preferentially'promotes TLRMediated Production of Type I Interferon. Nat. Immunol. 2009, 10, 744. [CrossRef]

148. Tseng, P.-H.; Matsuzawa, A.; Zhang, W.; Mino, T.; Vignali, D.A.A.; Karin, M. Different Modes of Ubiquitination of the Adaptor TRAF3 Selectively Activate the Expression of Type I Interferons and Proinflammatory Cytokines. Nat. Immunol. 2010, 11, 70-75. [CrossRef]

149. Gabhann, J.N.; Jefferies, C.A. TLR-Induced Activation of Btk-Role for Endosomal MHC Class II Molecules Revealed. Cell Res. 2011, 21, 998-1001. [CrossRef]

150. Frei, R.; Steinle, J.; Birchler, T.; Loeliger, S.; Roduit, C.; Steinhoff, D.; Seibl, R.; Büchner, K.; Seger, R.; Reith, W.; et al. MHC Class II Molecules Enhance Toll-like Receptor Mediated Innate Immune Responses. PLoS ONE 2010, 5, e8808. [CrossRef]

151. Hassan, G.S.; Mourad, W. An Unexpected Role for MHC Class II. Nat. Immunol. 2011, 12, 375-376. [CrossRef] 
152. Negi, S.; Singh, H.; Mukhopadhyay, A. Gut Bacterial Peptides with Autoimmunity Potential as Environmental Trigger for Late Onset Complex Diseases: In-Silico Study. PLoS ONE 2017, 12, e0180518. [CrossRef] [PubMed]

153. Matsuguchi, T.; Takagi, A.; Matsuzaki, T.; Nagaoka, M.; Ishikawa, K.; Yokokura, T.; Yoshikai, Y. Lipoteichoic Acids from Lactobacillus Strains Elicit Strong Tumor Necrosis Factor Alpha-Inducing Activities in Macrophages through Toll-like Receptor 2. Clin. Diagn. Lab. Immunol. 2003, 10, 259-266. [CrossRef] [PubMed]

154. Kim, H.G.; Lee, S.Y.; Kim, N.-R.; Ko, M.Y.; Lee, J.M.; Yi, T.-H.; Chung, S.K.; Chung, D.K. Inhibitory Effects of Lactobacillus Plantarum Lipoteichoic Acid (LTA) on Staphylococcus Aureus LTA-Induced Tumor Necrosis Factor-Alpha Production. J. Microbiol. Biotechnol. 2008, 18, 1191-1196. [PubMed]

155. Kim, H.G.; Kim, N.-R.; Gim, M.G.; Lee, J.M.; Lee, S.Y.; Ko, M.Y.; Kim, J.Y.; Han, S.H.; Chung, D.K. Lipoteichoic Acid Isolated from Lactobacillus Plantarum Inhibits Lipopolysaccharide-Induced TNF- $\alpha$ Production in THP-1 Cells and Endotoxin Shock in Mice. J. Immunol. 2008, 180, 2553-2561. [CrossRef]

156. Kim, H.G.; Lee, S.Y.; Kim, N.R.; Lee, H.Y.; Ko, M.Y.; Jung, B.J.; Kim, C.M.; Lee, J.M.; Park, J.H.; Han, S.H.; et al. Lactobacillus Plantarum Lipoteichoic Acid down-Regulated Shigella Flexneri Peptidoglycan-Induced Inflammation. Mol. Immunol. 2011, 48, 382-391. [CrossRef]

157. Claes, I.J.J.; Lebeer, S.; Shen, C.; Verhoeven, T.L.A.; Dilissen, E.; De Hertogh, G.; Bullens, D.M.A.; Ceuppens, J.L.; Van Assche, G.; Vermeire, S.; et al. Impact of Lipoteichoic Acid Modification on the Performance of the Probiotic Lactobacillus Rhamnosus GG in Experimental Colitis. Clin. Exp. Immunol. 2010, 162, 306-314. [CrossRef] [PubMed]

158. Grangette, C.; Nutten, S.; Palumbo, E.; Morath, S.; Hermann, C.; Dewulf, J.; Pot, B.; Hartung, T.; Hols, P.; Mercenier, A. Enhanced Antiinflammatory Capacity of a Lactobacillus Plantarum Mutant Synthesizing Modified Teichoic Acids. Proc. Natl. Acad. Sci. USA 2005, 102, 10321-10326. [CrossRef]

159. Jang, K.-S.; Baik, J.E.; Han, S.H.; Chung, D.K.; Kim, B.-G. Multi-Spectrometric Analyses of Lipoteichoic Acids Isolated from Lactobacillus Plantarum. Biochem. Biophys. Res. Commun. 2011, 407, 823-830. [CrossRef]

160. Hayashi, F.; Smith, K.D.; Ozinsky, A.; Hawn, T.R.; Yi, E.C.; Goodlett, D.R.; Eng, J.K.; Akira, S.; Underhill, D.M.; Aderem, A. The Innate Immune Response to Bacterial Flagellin Is Mediated by Toll-like Receptor 5. Nature 2001, 410, 1099-1103. [CrossRef]

161. Gewirtz, A.T. Flag in the Crossroads: Flagellin Modulates Innate and Adaptive Immunity. Curr. Opin. Gastroenterol. 2006, 22, 8-12. [CrossRef]

162. Ren, T.; Zamboni, D.S.; Roy, C.R.; Dietrich, W.F.; Vance, R.E. Flagellin-Deficient Legionella Mutants Evade Caspase-1- and Naip5-Mediated Macrophage Immunity. PLoS Pathogens 2006, 2, e18. [CrossRef]

163. Akira, S.; Uematsu, S.; Takeuchi, O. Pathogen Recognition and Innate Immunity. Cell 2006, 124, 783-801. [CrossRef] [PubMed]

164. Cullender, T.C.; Chassaing, B.; Janzon, A.; Kumar, K.; Muller, C.E.; Werner, J.J.; Angenent, L.T.; Bell, M.E.; Hay, A.G.; Peterson, D.A.; et al. Innate and Adaptive Immunity Interact to Quench Microbiome Flagellar Motility in the Gut. Cell Host Microbe 2013, 14, 571-581. [CrossRef] [PubMed]

165. Fulde, M.; Sommer, F.; Chassaing, B.; van Vorst, K.; Dupont, A.; Hensel, M.; Basic, M.; Klopfleisch, R.; Rosenstiel, P.; Bleich, A.; et al. Publisher Correction: Neonatal Selection by Toll-like Receptor 5 Influences Long-Term Gut Microbiota Composition. Nature 2018, 563, E25. [CrossRef]

166. Vijay-Kumar, M.; Aitken, J.D.; Sanders, C.J.; Frias, A.; Sloane, V.M.; Xu, J.; Neish, A.S.; Rojas, M.; Gewirtz, A.T. Flagellin Treatment Protects against Chemicals, Bacteria, Viruses, and Radiation. J. Immunol. 2008, 180, 8280-8285. [CrossRef] [PubMed]

167. Chassaing, B.; Ley, R.E.; Gewirtz, A.T. Intestinal Epithelial Cell Toll-like Receptor 5 Regulates the Intestinal Microbiota to Prevent Low-Grade Inflammation and Metabolic Syndrome in Mice. Gastroenterology 2014, 147, 1363-1377.e17. [CrossRef]

168. Lopetuso, L.R.; Jia, R.; Wang, X.-M.; Jia, L.-G.; Petito, V.; Goodman, W.A.; Meddings, J.B.; Cominelli, F.; Reuter, B.K.; Pizarro, T.T. Epithelial-Specific Toll-like Receptor (TLR)5 Activation Mediates Barrier Dysfunction in Experimental Ileitis. Inflamm. Bowel Dis. 2017, 23, 392-403. [CrossRef]

169. Vijay-Kumar, M.; Aitken, J.D.; Carvalho, F.A.; Cullender, T.C.; Mwangi, S.; Srinivasan, S.; Sitaraman, S.V.; Knight, R.; Ley, R.E.; Gewirtz, A.T. Metabolic Syndrome and Altered Gut Microbiota in Mice Lacking Toll-like Receptor 5. Science 2010, 328, $228-231$. [CrossRef] [PubMed]

170. Pekkala, S.; Munukka, E.; Kong, L.; Pöllänen, E.; Autio, R.; Roos, C.; Wiklund, P.; Fischer-Posovszky, P.; Wabitsch, M.; Alen, M.; et al. Toll-like Receptor 5 in Obesity: The Role of Gut Microbiota and Adipose Tissue Inflammation: Gut Microbiota, TLR5, Inflammation, and Obesity. Obesity 2015, 23, 581-590. [CrossRef]

171. Zhang, W.; Hartmann, R.; Tun, H.M.; Elson, C.O.; Khafipour, E.; Garvey, W.T. Deletion of the Toll-Like Receptor 5 Gene Per Se Does Not Determine the Gut Microbiome Profile That Induces Metabolic Syndrome: Environment Trumps Genotype. PLoS ONE 2016, 11, e0150943. [CrossRef]

172. Neville, B.A.; Forde, B.M.; Claesson, M.J.; Darby, T.; Coghlan, A.; Nally, K.; Ross, R.P.; O’Toole, P.W. Characterization of proInflammatory Flagellin Proteins Produced by Lactobacillus Ruminis and Related Motile Lactobacilli. PLoS ONE 2012, 7, e40592. [CrossRef]

173. Kajikawa, A.; Midorikawa, E.; Masuda, K.; Kondo, K.; Irisawa, T.; Igimi, S.; Okada, S. Characterization of Flagellins Isolated from a Highly Motile Strain of Lactobacillus Agilis. BMC Microbiol. 2016, 16, 49. [CrossRef]

174. Voogdt, C.G.P.; Bouwman, L.I.; Kik, M.J.L.; Wagenaar, J.A.; van Putten, J.P.M. Reptile Toll-like Receptor 5 Unveils Adaptive Evolution of Bacterial Flagellin Recognition. Sci. Rep. 2016, 6, 19046. [CrossRef] [PubMed] 
175. Schlee, M.; Wehkamp, J.; Altenhoefer, A.; Oelschlaeger, T.A.; Stange, E.F.; Fellermann, K. Induction of Human $\beta$-Defensin 2 by the Probiotic Escherichia Coli Nissle 1917 Is Mediated through Flagellin. Infect. Immun. 2007, 75, 2399-2407. [CrossRef]

176. Telford, J.L.; Barocchi, M.A.; Margarit, I.; Rappuoli, R.; Grandi, G. Pili in Gram-Positive Pathogens. Nat. Rev. Microbiol. 2006, 4, 509-519. [CrossRef]

177. Proft, T.; Baker, E.N. Pili in Gram-Negative and Gram-Positive Bacteria-structure, Assembly and Their Role in Disease. Cell. Mol. Life Sci. 2009, 66, 613. [CrossRef]

178. Kankainen, M.; Paulin, L.; Tynkkynen, S.; von Ossowski, I.; Reunanen, J.; Partanen, P.; Satokari, R.; Vesterlund, S.; Hendrickx, A.P.A.; Lebeer, S.; et al. Comparative Genomic Analysis of Lactobacillus Rhamnosus GG Reveals Pili Containing a HumanMucus Binding Protein. Proc. Natl. Acad. Sci. USA 2009, 106, 17193-17198. [CrossRef] [PubMed]

179. Yu, X.; Jaatinen, A.; Rintahaka, J.; Hynönen, U.; Lyytinen, O.; Kant, R.; Åvall-Jääskeläinen, S.; von Ossowski, I.; Palva, A. Human Gut-Commensalic Lactobacillus Ruminis ATCC 25644 Displays Sortase-Assembled Surface Piliation: Phenotypic Characterization of Its Fimbrial Operon through In Silico Predictive Analysis and Recombinant Expression in Lactococcus Lactis. PLoS ONE 2015, 10, e0145718. [CrossRef]

180. Lebeer, S.; Claes, I.; Tytgat, H.L.P.; Verhoeven, T.L.A.; Marien, E.; von Ossowski, I.; Reunanen, J.; Palva, A.; de Vos, W.M.; Keersmaecker, S.C.J.D.; et al. Functional Analysis of Lactobacillus Rhamnosus GG Pili in Relation to Adhesion and Immunomodulatory Interactions with Intestinal Epithelial Cells. Appl. Environ. Microbiol. 2012, 78, 185-193. [CrossRef]

181. Chaurasia, P.; Pratap, S.; von Ossowski, I.; Palva, A.; Krishnan, V. New Insights about Pilus Formation in Gut-Adapted Lactobacillus Rhamnosus GG from the Crystal Structure of the SpaA Backbone-Pilin Subunit. Sci. Rep. 2016, 6, 28664. [CrossRef]

182. Granato, D.; Bergonzelli, G.E.; Pridmore, R.D.; Marvin, L.; Rouvet, M.; Corthésy-Theulaz, I.E. Cell Surface-Associated Elongation Factor Tu Mediates the Attachment of Lactobacillus Johnsonii NCC533 (La1) to Human Intestinal Cells and Mucins. Infect. Immun. 2004, 72, 2160-2169. [CrossRef] [PubMed]

183. Bergonzelli, G.E.; Granato, D.; Pridmore, R.D.; Marvin-Guy, L.F.; Donnicola, D.; Corthésy-Theulaz, I.E. GroEL of Lactobacillus Johnsonii La1 (NCC 533) Is Cell Surface Associated: Potential Role in Interactions with the Host and the Gastric Pathogen Helicobacter Pylori. Infect. Immun. 2006, 74, 425-434. [CrossRef] [PubMed]

184. Finberg, R.W.; Kurt-Jones, E.A. CD14: Chaperone or Matchmaker? Immunity 2006, 24, 127-129. [CrossRef] [PubMed]

185. Zanoni, I.; Ostuni, R.; Marek, L.R.; Barresi, S.; Barbalat, R.; Barton, G.M.; Granucci, F.; Kagan, J.C. CD14 Controls the LPS-Induced Endocytosis of Toll-like Receptor 4. Cell 2011, 147, 868-880. [CrossRef] [PubMed]

186. Hsu, K.; Chung, Y.M.; Endoh, Y.; Geczy, C.L. TLR9 Ligands Induce S100A8 in Macrophages via a STAT3-Dependent Pathway Which Requires IL-10 and PGE2. PLoS ONE 2014, 9, e103629. [CrossRef] [PubMed]

187. Hornung, V.; Rothenfusser, S.; Britsch, S.; Krug, A.; Jahrsdörfer, B.; Giese, T.; Endres, S.; Hartmann, G. Quantitative Expression of Toll-like Receptor 1-10 mRNA in Cellular Subsets of Human Peripheral Blood Mononuclear Cells and Sensitivity to CpG Oligodeoxynucleotides. J. Immunol. 2002, 168, 4531-4537. [CrossRef]

188. Kadowaki, N.; Ho, S.; Antonenko, S.; Malefyt, R.W.; Kastelein, R.A.; Bazan, F.; Liu, Y.J. Subsets of Human Dendritic Cell Precursors Express Different Toll-like Receptors and Respond to Different Microbial Antigens. J. Exp. Med. 2001, 194, 863-869. [CrossRef]

189. Schneberger, D.; Caldwell, S.; Kanthan, R.; Singh, B. Expression of Toll-like Receptor 9 in Mouse and Human Lungs. J. Anat. 2013, 222, 495-503. [CrossRef]

190. Dalpke, A.; Frank, J.; Peter, M.; Heeg, K. Activation of Toll-like Receptor 9 by DNA from Different Bacterial Species. Infect. Immun. 2006, 74, 940-946. [CrossRef]

191. Klinman, D.M.; Yamshchikov, G.; Ishigatsubo, Y. Contribution of CpG Motifs to the Immunogenicity of DNA Vaccines. J. Immunol. 1997, 158, 3635-3639.

192. Bode, C.; Zhao, G.; Steinhagen, F.; Kinjo, T. CpG DNA as a Vaccine Adjuvant. Rev. Vaccines 2011, 10, 499-511. [CrossRef]

193. Zhong, Y.; Huang, J.; Tang, W.; Chen, B.; Cai, W. Effects of Probiotics, Probiotic DNA and the CpG Oligodeoxynucleotides on Ovalbumin-Sensitized Brown-Norway Rats via TLR9/NF-кB Pathway. FEMS Immunol. Med. Microbiol. 2012, 66, 71-82. [CrossRef]

194. Iliev, I.D.; Kitazawa, H.; Shimosato, T.; Katoh, S.; Morita, H.; He, F.; Hosoda, M.; Saito, T. Strong Immunostimulation in Murine Immune Cells by Lactobacillus Rhamnosus GG DNA Containing Novel Oligodeoxynucleotide Pattern. Cell. Microbiol. 2005, 7, 403-414. [CrossRef]

195. Iliev, I.D.; Tohno, M.; Kurosaki, D.; Shimosato, T.; He, F.; Hosoda, M.; Saito, T.; Kitazawa, H. Immunostimulatory Oligodeoxynucleotide Containing TTTCGTTT Motif from Lactobacillus Rhamnosus GG DNA Potentially Suppresses OVA-Specific IgE Production in Mice. Scand. J. Immunol. 2008, 67, 370-376. [CrossRef] [PubMed]

196. Kant, R.; de Vos, W.M.; Palva, A.; Satokari, R. Immunostimulatory CpG Motifs in the Genomes of Gut Bacteria and Their Role in Human Health and Disease. J. Med. Microbiol. 2014, 63, 293-308. [CrossRef]

197. Watson, J.L.; McKay, D.M. The Immunophysiological Impact of Bacterial CpG DNA on the Gut. Clin. Chim. Acta 2006, 364, 1-11. [CrossRef] [PubMed]

198. Ghadimi, D.; Fölster-Holst, R.; de Vrese, M.; Winkler, P.; Heller, K.J.; Schrezenmeir, J. Effects of Probiotic Bacteria and Their Genomic DNA on TH1/TH2-Cytokine Production by Peripheral Blood Mononuclear Cells (PBMCs) of Healthy and Allergic Subjects. Immunobiology 2008, 213, 677-692. [CrossRef] [PubMed] 
199. Grüber, C.; Wendt, M.; Sulser, C.; Lau, S.; Kulig, M.; Wahn, U.; Werfel, T.; Niggemann, B. Randomized, Placebo-Controlled Trial of Lactobacillus Rhamnosus GG as Treatment of Atopic Dermatitis in Infancy. Allergy 2007, 62, 1270-1276. [CrossRef]

200. Odamaki, T.; Xiao, J.-Z.; Iwabuchi, N.; Sakamoto, M.; Takahashi, N.; Kondo, S.; Miyaji, K.; Iwatsuki, K.; Togashi, H.; Enomoto, T.; et al. Influence of Bifidobacterium Longum BB536 Intake on Faecal Microbiota in Individuals with Japanese Cedar Pollinosis during the Pollen Season. J. Med. Microbiol. 2007, 56, 1301-1308. [CrossRef]

201. Qi, S.R.; Cui, Y.J.; Liu, J.X.; Luo, X.; Wang, H.F. Lactobacillus Rhamnosus GG Components, SLP, gDNA and CpG, Exert Protective Effects on Mouse Macrophages upon Lipopolysaccharide Challenge. Lett. Appl. Microbiol. 2020, 70, 118-127. [CrossRef]

202. Hee Kim, C.; Geun Kim, H.; Yun Kim, J.; Ra Kim, N.; Jun Jung, B.; Hye Jeong, J.; Kyun Chung, D. Probiotic Genomic DNA Reduces the Production of pro-Inflammatory Cytokine Tumor Necrosis Factor-Alpha. FEMS Microbiol. Lett. 2012, 328, 13-19. [CrossRef] [PubMed]

203. Hassan, M.; Kjos, M.; Nes, I.F.; Diep, D.B.; Lotfipour, F. Natural Antimicrobial Peptides from Bacteria: Characteristics and Potential Applications to Fight against Antibiotic Resistance. J. Appl. Microbiol. 2012, 113, 723-736. [CrossRef]

204. Dobson, A.; Cotter, P.D.; Ross, R.P.; Hill, C. Bacteriocin Production: A Probiotic Trait? Appl. Environ. Microbiol. 2012, 78, 1-6. [CrossRef] [PubMed]

205. Lee, J.-H.; Karamychev, V.N.; Kozyavkin, S.A.; Mills, D.; Pavlov, A.R.; Pavlova, N.V.; Polouchine, N.N.; Richardson, P.M.; Shakhova, V.V.; Slesarev, A.I.; et al. Comparative Genomic Analysis of the Gut Bacterium Bifidobacterium Longum Reveals Loci Susceptible to Deletion during Pure Culture Growth. BMC Genom. 2008, 9, 247. [CrossRef] [PubMed]

206. Walsh, M.C.; Gardiner, G.E.; Hart, O.M.; Lawlor, P.G.; Daly, M.; Lynch, B.; Richert, B.T.; Radcliffe, S.; Giblin, L.; Hill, C.; et al. Predominance of a Bacteriocin-Producing Lactobacillus Salivarius Component of a Five-Strain Probiotic in the Porcine Ileum and Effects on Host Immune Phenotype. FEMS Microbiol. Ecol. 2008, 64, 317-327. [CrossRef]

207. O'Shea, E.F.; Gardiner, G.E.; O'Connor, P.M.; Mills, S.; Paul Ross, R.; Hill, C. Characterization of Enterocin- and SalivaricinProducing Lactic Acid Bacteria from the Mammalian Gastrointestinal Tract. FEMS Microbiol. Lett. 2009, 291, 24-34. [CrossRef] [PubMed]

208. O'Shea, E.F.; O'Connor, P.M.; Raftis, E.J.; O'Toole, P.W.; Stanton, C.; Cotter, P.D.; Ross, R.P.; Hill, C. Production of Multiple Bacteriocins from a Single Locus by Gastrointestinal Strains of Lactobacillus Salivarius. J. Bacteriol. 2011, 193, 6973-6982. [CrossRef]

209. Gordon, D.M.; O’Brien, C.L. Bacteriocin Diversity and the Frequency of Multiple Bacteriocin Production in Escherichia Coli. Microbiology 2006, 152, 3239-3244. [CrossRef]

210. Drissi, F.; Buffet, S.; Raoult, D.; Merhej, V. Common Occurrence of Antibacterial Agents in Human Intestinal Microbiota. Front. Microbiol. 2015, 6, 1-8. [CrossRef]

211. Lakshminarayanan, B.; Guinane, C.M.; O'Connor, P.M.; Coakley, M.; Hill, C.; Stanton, C.; O’Toole, P.W.; Ross, R.P. Isolation and Characterization of Bacteriocin-Producing Bacteria from the Intestinal Microbiota of Elderly Irish Subjects. J. Appl. Microbiol. 2013, 114, 886-898. [CrossRef]

212. Håversen, L.; Ohlsson, B.G.; Hahn-Zoric, M.; Hanson, L.Å.; Mattsby-Baltzer, I. Lactoferrin down-Regulates the LPS-Induced Cytokine Production in Monocytic Cells via NF-kB. Cell. Immunol. 2002, 220, 83-95. [CrossRef]

213. Davidson, D.J.; Currie, A.J.; Reid, G.S.D.; Bowdish, D.M.E.; MacDonald, K.L.; Ma, R.C.; Hancock, R.E.W.; Speert, D.P. The Cationic Antimicrobial Peptide LL-37 Modulates Dendritic Cell Differentiation and Dendritic Cell-Induced T Cell Polarization. J. Immunol. 2004, 172, 1146-1156. [CrossRef] [PubMed]

214. Mookherjee, N.; Brown, K.L.; Bowdish, D.M.E.; Doria, S.; Falsafi, R.; Hokamp, K.; Roche, F.M.; Mu, R.; Doho, G.H.; Pistolic, J.; et al. Modulation of the TLR-Mediated Inflammatory Response by the Endogenous Human Host Defense Peptide LL-37. J. Immunol. 2006, 176, 2455-2464. [CrossRef]

215. Lai, Y.; Gallo, R.L. AMPed up Immunity: How Antimicrobial Peptides Have Multiple Roles in Immune Defense. Trends Immunol. 2009, 30, 131-141. [CrossRef] [PubMed]

216. van der Does, A.M.; Bogaards, S.J.P.; Ravensbergen, B.; Beekhuizen, H.; van Dissel, J.T.; Nibbering, P.H. Antimicrobial Peptide hLF1-11 Directs Granulocyte-Macrophage Colony-Stimulating Factor-Driven Monocyte Differentiation toward Macrophages with Enhanced Recognition and Clearance of Pathogens. Antimicrob. Agents Chemother. 2010, 54, 811-816. [CrossRef]

217. Yeung, A.T.Y.; Gellatly, S.L.; Hancock, R.E.W. Multifunctional Cationic Host Defence Peptides and Their Clinical Applications. Cell. Mol. Life Sci. 2011, 68, 2161-2176. [CrossRef]

218. Choi, K.-Y.; Chow, L.N.Y.; Mookherjee, N. Cationic Host Defence Peptides: Multifaceted Role in Immune Modulation and Inflammation. J. Innate Immun. 2012, 4, 361-370. [CrossRef]

219. Scheenstra, M.R.; van Harten, R.M.; Veldhuizen, E.J.A.; Haagsman, H.P.; Coorens, M. Cathelicidins Modulate TLR-Activation and Inflammation. Front. Immunol. 2020, 11, 1137. [CrossRef]

220. Nagaoka, I.; Hirota, S.; Niyonsaba, F.; Hirata, M.; Adachi, Y.; Tamura, H.; Tanaka, S.; Heumann, D. Augmentation of the Lipopolysaccharide-Neutralizing Activities of Human Cathelicidin CAP18/LL-37-Derived Antimicrobial Peptides by Replacement with Hydrophobic and Cationic Amino Acid Residues. Clin. Vaccine Immunol. 2002, 9, 972-982. [CrossRef]

221. Lanne, A.B.M.; Goode, A.; Prattley, C.; Kumari, D.; Drasbek, M.R.; Williams, P.; Conde-Álvarez, R.; Moriyón, I.; Bonev, B.B. Molecular Recognition of Lipopolysaccharide by the Lantibiotic Nisin. Biochim. Biophys. Acta Biomembr. 2019, 1861, 83-92. [CrossRef] [PubMed] 
222. Lee, Y.J.; Choi, H.J.; Kang, T.W.; Kim, H.O.; Chung, M.J.; Park, Y.M. CBT-SL5, a Bacteriocin from Enterococcus Faecalis, Suppresses the Expression of Interleukin-8 Induced by Propionibacterium Acnes in Cultured Human Keratinocytes. J. Microbiol. Biotechnol. 2008, 18, 1308-1316. [PubMed]

223. Sand, S.L.; Oppegård, C.; Ohara, S.; Iijima, T.; Naderi, S.; Blomhoff, H.K.; Nissen-Meyer, J.; Sand, O. Plantaricin A, a Peptide Pheromone Produced by Lactobacillus Plantarum, Permeabilizes the Cell Membrane of Both Normal and Cancerous Lymphocytes and Neuronal Cells. Peptides 2010, 31, 1237-1244. [CrossRef] [PubMed]

224. Pinto, D.; Marzani, B.; Minervini, F.; Calasso, M.; Giuliani, G.; Gobbetti, M.; De Angelis, M. Plantaricin A Synthesized by Lactobacillus Plantarum Induces in Vitro Proliferation and Migration of Human Keratinocytes and Increases the Expression of TGF- $\beta 1$, FGF7, VEGF-A and IL-8 Genes. Peptides 2011, 32, 1815-1824. [CrossRef]

225. Begde, D.; Bundale, S.; Mashitha, P.; Rudra, J.; Nashikkar, N.; Upadhyay, A. Immunomodulatory Efficacy of Nisin—a Bacterial Lantibiotic Peptide. J. Pept. Sci. 2011, 17, 438-444. [CrossRef] [PubMed]

226. Kindrachuk, J.; Jenssen, H.; Elliott, M.; Nijnik, A.; Magrangeas-Janot, L.; Pasupuleti, M.; Thorson, L.; Ma, S.; Easton, D.M.; Bains, M.; et al. Manipulation of Innate Immunity by a Bacterial Secreted Peptide: Lantibiotic Nisin Z Is Selectively Immunomodulatory. Innate Immun. 2013, 19, 315-327. [CrossRef]

227. Malvisi, M.; Stuknyte, M.; Magro, G.; Minozzi, G.; Giardini, A.; De Noni, I.; Piccinini, R. Antibacterial Activity and Immunomodulatory Effects on a Bovine Mammary Epithelial Cell Line Exerted by Nisin A-Producing Lactococcus Lactis Strains. J. Dairy Sci. 2016, 99, 2288-2296. [CrossRef] [PubMed]

228. Molhoek, E.M.; Margo Molhoek, E.; den Hertog, A.L.; de Vries, A.-M.B.C.; Nazmi, K.; Veerman, E.C.I.; Hartgers, F.C.; Yazdanbakhsh, M.; Bikker, F.J.; van der Kleij, D. Structure-Function Relationship of the Human Antimicrobial Peptide LL-37 and LL-37 Fragments in the Modulation of TLR Responses. Biol. Chem. 2009, 390, 295-303. [CrossRef] [PubMed]

229. Nagaoka, I.; Hirota, S.; Niyonsaba, F.; Hirata, M.; Adachi, Y.; Tamura, H.; Heumann, D. Cathelicidin Family of Antibacterial Peptides CAP18 and CAP11 Inhibit the Expression of TNF- $\alpha$ by Blocking the Binding of LPS to CD14 Cells. J. Immunol. 2001, 167, 3329-3338. [CrossRef] [PubMed]

230. Rosenfeld, Y.; Papo, N.; Shai, Y. Endotoxin (lipopolysaccharide) Neutralization by Innate Immunity Host-Defense Peptides. Peptide Properties and Plausible Modes of Action. J. Biol. Chem. 2006, 281, 1636-1643. [CrossRef] [PubMed]

231. Jia, Z.; He, M.; Wang, C.; Chen, A.; Zhang, X.; Xu, J.; Fu, H.; Liu, B. Nisin Reduces Uterine Inflammation in Rats by Modulating Concentrations of Pro- and Anti-inflammatory Cytokines. Am. J. Reprod. Immunol. 2019, 81, e13096. [CrossRef]

232. Anitha, M.; Vijay-Kumar, M.; Sitaraman, S.V.; Gewirtz, A.T.; Srinivasan, S. Gut Microbial Products Regulate Murine Gastrointestinal Motility via Toll-Like Receptor 4 Signaling. Gastroenterology 2012, 143, 1006-1016.e4. [CrossRef]

233. Brun, P.; Giron, M.C.; Qesari, M.; Porzionato, A.; Caputi, V.; Zoppellaro, C.; Banzato, S.; Grillo, A.R.; Spagnol, L.; De Caro, R.; et al. Toll-Like Receptor 2 Regulates Intestinal Inflammation by Controlling Integrity of the Enteric Nervous System. Gastroenterology 2013, 145, 1323-1333. [CrossRef] [PubMed]

234. Sepehri, Z.; Kiani, Z.; Kohan, F.; Alavian, S.M.; Ghavami, S. Toll like Receptor 4 and Hepatocellular Carcinoma; A Systematic Review. Life Sci. 2017, 179, 80-87. [CrossRef]

235. Etienne-Mesmin, L.; Vijay-Kumar, M.; Gewirtz, A.T.; Chassaing, B. Hepatocyte Toll-Like Receptor 5 Promotes Bacterial Clearance and Protects Mice Against High-Fat Diet-Induced Liver Disease. Cell. Mol. Gastroenterol. Hepatol. 2016, 2, 584-604. [CrossRef]

236. Zou, H.; Wang, W.-K.; Liu, Y.-L.; Braddock, M.; Zheng, M.-H.; Huang, D.-S. Toll-like Receptors in Hepatocellular Carcinoma: Potential Novel Targets for Pharmacological Intervention. Expert Opin. Ther. Targets 2016, 20, 1127-1135. [CrossRef]

237. Lee, Y.-S.; Kim, Y.-H.; Jung, Y.S.; Kim, K.-S.; Kim, D.-K.; Na, S.-Y.; Lee, J.-M.; Lee, C.-H.; Choi, H.-S. Hepatocyte Toll-like Receptor 4 Mediates Lipopolysaccharide-Induced Hepcidin Expression. Exp. Mol. Med. 2017, 49, e408. [CrossRef]

238. Zhang, C.; Yang, M.; Ericsson, A.C. Antimicrobial Peptides: Potential Application in Liver Cancer. Front. Microbiol. 2019, $10,1257$. [CrossRef] [PubMed]

239. Spadoni, I.; Zagato, E.; Bertocchi, A.; Paolinelli, R.; Hot, E.; Di Sabatino, A.; Caprioli, F.; Bottiglieri, L.; Oldani, A.; Viale, G.; et al. A Gut-Vascular Barrier Controls the Systemic Dissemination of Bacteria. Science 2015, 350, 830-834. [CrossRef]

240. Dreyer, L. The Ability of Antimicrobial Peptides to Migrate across the Gastrointestinal Epithelial and Vascular Endothelial Barriers; Stellenbosch University: Stellenbosch, South Africa, 2018.

241. Girardin, S.E.; Boneca, I.G.; Carneiro, L.A.M.; Antignac, A.; Jéhanno, M.; Viala, J.; Tedin, K.; Taha, M.-K.; Labigne, A.; Zähringer, U.; et al. Nod1 Detects a Unique Muropeptide from Gram-Negative Bacterial Peptidoglycan. Science 2003, 300, 1584-1587. [CrossRef]

242. Zhao, Y.; Yang, J.; Shi, J.; Gong, Y.-N.; Lu, Q.; Xu, H.; Liu, L.; Shao, F. The NLRC4 Inflammasome Receptors for Bacterial Flagellin and Type III Secretion Apparatus. Nature 2011, 477, 596-600. [CrossRef] [PubMed]

243. Rayamajhi, M.; Zak, D.E.; Chavarria-Smith, J.; Vance, R.E.; Miao, E.A. Cutting Edge: Mouse NAIP1 Detects the Type III Secretion System Needle Protein. J. Immunol. 2013, 191, 3986-3989. [CrossRef]

244. Liwinski, T.; Zheng, D.; Elinav, E. The Microbiome and Cytosolic Innate Immune Receptors. Immunol. Rev. 2020, $297,207-224$. [CrossRef]

245. Christgen, S.; Kanneganti, T.-D. Inflammasomes and the Fine Line between Defense and Disease. Curr. Opin. Immunol. 2020, 62, 39-44. [CrossRef] [PubMed]

246. Swanson, K.V.; Deng, M.; Ting, J.P.-Y. The NLRP3 Inflammasome: Molecular Activation and Regulation to Therapeutics. Nat. Rev. Immunol. 2019, 19, 477-489. [CrossRef] [PubMed] 
247. Wells, J.M.; Rossi, O.; Meijerink, M. Epithelial Crosstalk at the Microbiota-mucosal Interface. Proc. Natl. Acad. Sci. USA 2011, 108, 4607-4614. [CrossRef]

248. Mukherjee, T.; Hovingh, E.S.; Foerster, E.G.; Abdel-Nour, M.; Philpott, D.J.; Girardin, S.E. NOD1 and NOD2 in Inflammation, Immunity and Disease. Arch. Biochem. Biophys. 2019, 670, 69-81. [CrossRef] [PubMed]

249. Cario, E. Bacterial Interactions with Cells of the Intestinal Mucosa: Toll-like Receptors and NOD2. Gut 2005, 54, 1182-1193. [CrossRef]

250. McDaniel, M.M.; Kottyan, L.C.; Singh, H.; Pasare, C. Suppression of Inflammasome Activation by IRF8 and IRF4 in cDCs Is Critical for T Cell Priming. Cell Rep. 2020, 31, 107604.

251. Nagyőszi, P.; Nyúl-Tóth, Á; Fazakas, C.; Wilhelm, I.; Kozma, M.; Molnár, J.; Haskó, J.; Krizbai, I.A. Regulation of NOD-like Receptors and Inflammasome Activation in Cerebral Endothelial Cells. J. Neurochem. 2015, 135, 551-564. [CrossRef] [PubMed]

252. Clarke, T.B.; Davis, K.M.; Lysenko, E.S.; Zhou, A.Y.; Yu, Y.; Weiser, J.N. Recognition of Peptidoglycan from the Microbiota by Nod1 Enhances Systemic Innate Immunity. Nat. Med. 2010, 16, 228-231. [CrossRef]

253. Chen, G.Y.; Shaw, M.H.; Redondo, G.; Núñez, G. The Innate Immune Receptor Nod1 Protects the Intestine from InflammationInduced Tumorigenesis. Cancer Res. 2008, 68, 10060-10067. [CrossRef]

254. Jung, C.; Hugot, J.-P.; Barreau, F. Peyer's Patches: The Immune Sensors of the Intestine. Int. J. Inflam. 2010, $2010,823710$. [CrossRef]

255. Barreau, F.; Madre, C.; Meinzer, U.; Berrebi, D.; Dussaillant, M.; Merlin, F.; Eckmann, L.; Karin, M.; Sterkers, G.; Bonacorsi, S.; et al. Nod2 Regulates the Host Response towards Microflora by Modulating T Cell Function and Epithelial Permeability in Mouse Peyer's Patches. Gut 2010, 59, 207-217. [CrossRef]

256. Kobayashi, K.S.; Chamaillard, M.; Ogura, Y.; Henegariu, O.; Inohara, N.; Nuñez, G.; Flavell, R.A. Nod2-Dependent Regulation of Innate and Adaptive Immunity in the Intestinal Tract. Science 2005, 307, 731-734. [CrossRef] [PubMed]

257. Al Nabhani, Z.; Lepage, P.; Mauny, P.; Montcuquet, N.; Roy, M.; Le Roux, K.; Dussaillant, M.; Berrebi, D.; Hugot, J.-P.; Barreau, F. Nod2 Deficiency Leads to a Specific and Transmissible Mucosa-Associated Microbial Dysbiosis Which Is Independent of the Mucosal Barrier Defect. J. Crohns. Colitis 2016, 10, 1428-1436. [CrossRef]

258. Ramanan, D.; Tang, M.S.; Bowcutt, R.; Loke, P. 'ng; Cadwell, K. Bacterial Sensor Nod2 Prevents Inflammation of the Small Intestine by Restricting the Expansion of the Commensal Bacteroides Vulgatus. Immunity 2014, 41, 311-324. [CrossRef] [PubMed]

259. Hugot, J.P.; Chamaillard, M.; Zouali, H.; Lesage, S.; Cézard, J.P.; Belaiche, J.; Almer, S.; Tysk, C.; O’Morain, C.A.; Gassull, M.; et al. Association of NOD2 Leucine-Rich Repeat Variants with Susceptibility to Crohn's Disease. Nature 2001, 411, 599-603. [CrossRef] [PubMed]

260. Imhann, F.; Vich Vila, A.; Bonder, M.J.; Fu, J.; Gevers, D.; Visschedijk, M.C.; Spekhorst, L.M.; Alberts, R.; Franke, L.; van Dullemen, H.M.; et al. Interplay of Host Genetics and Gut Microbiota Underlying the Onset and Clinical Presentation of Inflammatory Bowel Disease. Gut 2018, 67, 108-119. [CrossRef]

261. Schertzer, J.D.; Tamrakar, A.K.; Magalhães, J.G.; Pereira, S.; Bilan, P.J.; Fullerton, M.D.; Liu, Z.; Steinberg, G.R.; Giacca, A.; Philpott, D.J.; et al. NOD1 Activators Link Innate Immunity to Insulin Resistance. Diabetes 2011, 60, 2206-2215. [CrossRef] [PubMed]

262. Chan, K.L.; Tam, T.H.; Boroumand, P.; Prescott, D.; Costford, S.R.; Escalante, N.K.; Fine, N.; Tu, Y.; Robertson, S.J.; Prabaharan, D.; et al. Circulating NOD1 Activators and Hematopoietic NOD1 Contribute to Metabolic Inflammation and Insulin Resistance. Cell Rep. 2017, 18, 2415-2426. [CrossRef]

263. Denou, E.; Lolmède, K.; Garidou, L.; Pomie, C.; Chabo, C.; Lau, T.C.; Fullerton, M.D.; Nigro, G.; Zakaroff-Girard, A.; Luche, E.; et al. Defective NOD2 Peptidoglycan Sensing Promotes Diet-Induced Inflammation, Dysbiosis, and Insulin Resistance. EMBO Mol. Med. 2015, 7, 259-274. [CrossRef]

264. Cavallari, J.F.; Fullerton, M.D.; Duggan, B.M.; Foley, K.P.; Denou, E.; Smith, B.K.; Desjardins, E.M.; Henriksbo, B.D.; Kim, K.J.; Tuinema, B.R.; et al. Muramyl Dipeptide-Based Postbiotics Mitigate Obesity-Induced Insulin Resistance via IRF4. Cell Metab. 2017, 25, 1063-1074.e3. [CrossRef] [PubMed]

265. Watanabe, T.; Asano, N.; Meng, G.; Yamashita, K.; Arai, Y.; Sakurai, T.; Kudo, M.; Fuss, I.J.; Kitani, A.; Shimosegawa, T.; et al. NOD2 Downregulates Colonic Inflammation by IRF4-Mediated Inhibition of K63-Linked Polyubiquitination of RICK and TRAF6. Mucosal Immunol. 2014, 7, 1312-1325. [CrossRef]

266. Cavallari, J.F.; Barra, N.G.; Foley, K.P.; Lee, A.; Duggan, B.M.; Henriksbo, B.D.; Anhê, F.F.; Ashkar, A.A.; Schertzer, J.D. Postbiotics for NOD2 Require Nonhematopoietic RIPK2 to Improve Blood Glucose and Metabolic Inflammation in Mice. Am. J. Physiol. Endocrinol. Metab. 2020, 318, E579-E585. [CrossRef]

267. Zeuthen, L.H.; Fink, L.N.; Frøkiaer, H. Toll-like Receptor 2 and Nucleotide-Binding Oligomerization Domain-2 Play Divergent Roles in the Recognition of Gut-Derived Lactobacilli and Bifidobacteria in Dendritic Cells. Immunology 2008, 124, 489-502. [CrossRef]

268. Foligne, B.; Zoumpopoulou, G.; Dewulf, J.; Ben Younes, A.; Chareyre, F.; Sirard, J.-C.; Pot, B.; Grangette, C. A Key Role of Dendritic Cells in Probiotic Functionality. PLoS ONE 2007, 2, e313. [CrossRef] [PubMed]

269. Kwon, H.K.; Lee, C.G.; So, J.S.; Chae, C.S. Generation of Regulatory Dendritic Cells and CD4+ Foxp3+ T Cells by Probiotics Administration Suppresses Immune Disorders. Proc. Natl. Acad. Sci. USA 2010, 107, 2159-2164. [CrossRef]

270. Kolling, Y.; Salva, S.; Villena, J.; Marranzino, G.; Alvarez, S. Non-Viable Immunobiotic Lactobacillus Rhamnosus CRL1505 and Its Peptidoglycan Improve Systemic and Respiratory Innate Immune Response during Recovery of ImmunocompromisedMalnourished Mice. Int. Immunopharmacol. 2015, 25, 474-484. [CrossRef] 
271. Kolling, Y.; Salva, S.; Villena, J.; Alvarez, S. Are the Immunomodulatory Properties of Lactobacillus Rhamnosus CRL1505 Peptidoglycan Common for All Lactobacilli during Respiratory Infection in Malnourished Mice? PLoS ONE 2018, 13, e0194034. [CrossRef]

272. Melnyk, J.E.; Mohanan, V.; Schaefer, A.K.; Hou, C.-W.; Grimes, C.L. Peptidoglycan Modifications Tune the Stability and Function of the Innate Immune Receptor Nod2. J. Am. Chem. Soc. 2015, 137, 6987-6990. [CrossRef] [PubMed]

273. Vollmer, W. Structural Variation in the Glycan Strands of Bacterial Peptidoglycan. FEMS Microbiol. Rev. 2008, 32, 287-306. [CrossRef]

274. Wolf, A.J.; Reyes, C.N.; Liang, W.; Becker, C.; Shimada, K.; Wheeler, M.L.; Cho, H.C.; Popescu, N.I.; Coggeshall, K.M.; Arditi, M.; et al. Hexokinase Is an Innate Immune Receptor for the Detection of Bacterial Peptidoglycan. Cell 2016, 166, 624-636. [CrossRef]

275. Bernard, E.; Rolain, T.; Courtin, P.; Hols, P.; Chapot-Chartier, M.-P. Identification of the Amidotransferase AsnB1 as Being Responsible Formeso-Diaminopimelic Acid Amidation in Lactobacillus Plantarum Peptidoglycan. J. Bacteriol. 2011, 193, 6323-6330. [CrossRef] [PubMed]

276. Vijayrajratnam, S.; Pushkaran, A.C.; Balakrishnan, A.; Vasudevan, A.K.; Biswas, R.; Mohan, C.G. Bacterial Peptidoglycan with Amidated Meso-Diaminopimelic Acid Evades NOD1 Recognition: An Insight into NOD1 Structure-recognition. Biochem. J 2016, 473, 4573-4592. [CrossRef]

277. Bernard, E.; Rolain, T.; David, B.; André, G.; Dupres, V.; Dufrêne, Y.F.; Hallet, B.; Chapot-Chartier, M.-P.; Hols, P. Dual Role for the O-Acetyltransferase OatA in Peptidoglycan Modification and Control of Cell Septation in Lactobacillus Plantarum. PLoS ONE 2012, 7, e47893. [CrossRef] [PubMed]

278. Nagaoka, M.; Muto, M.; Nomoto, K.; Matuzaki, T.; Watanabe, T.; Yokokura, T. Structure of Polysaccharide-Peptidoglycan Complex from the Cell Wall of Lactobacillus Casei YIT9018. J. Biochem. 1990, 108, 568-571. [CrossRef] [PubMed]

279. Matsumoto, S.; Hara, T.; Nagaoka, M.; Mike, A.; Mitsuyama, K.; Sako, T.; Yamamoto, M.; Kado, S.; Takada, T. A Component of Polysaccharide Peptidoglycan Complex on Lactobacillus Induced an Improvement of Murine Model of Inflammatory Bowel Disease and Colitis-Associated Cancer. Immunology 2009, 128, e170-e180. [CrossRef] [PubMed]

280. Shida, K.; Kiyoshima-Shibata, J.; Kaji, R.; Nagaoka, M.; Nanno, M. Peptidoglycan from Lactobacilli Inhibits Interleukin12 Production by Macrophages Induced by Lactobacillus Casei through Toll-like Receptor 2-Dependent and Independent Mechanisms. Immunology 2009, 128, e858-e869. [CrossRef]

281. Wolf, A.J.; Underhill, D.M. Peptidoglycan Recognition by the Innate Immune System. Nat. Rev. Immunol. 2018, 18, 243-254. [CrossRef]

282. Clua, P.; Kanmani, P.; Zelaya, H.; Tada, A.; Kober, A.K.M.H.; Salva, S.; Alvarez, S.; Kitazawa, H.; Villena, J. Peptidoglycan from Immunobiotic Lactobacillus Rhamnosus Improves Resistance of Infant Mice to Respiratory Syncytial Viral Infection and Secondary Pneumococcal Pneumonia. Front. Immunol. 2017, 8, 948. [CrossRef]

283. Kozakova, H.; Schwarzer, M.; Tuckova, L.; Srutkova, D.; Czarnowska, E.; Rosiak, I.; Hudcovic, T.; Schabussova, I.; Hermanova, P.; Zakostelska, Z.; et al. Colonization of Germ-Free Mice with a Mixture of Three Lactobacillus Strains Enhances the Integrity of Gut Mucosa and Ameliorates Allergic Sensitization. Cell. Mol. Immunol. 2016, 13, 251-262. [CrossRef]

284. Guo, H.; Gibson, S.A.; Ting, J.P.Y. Gut Microbiota, NLR Proteins, and Intestinal Homeostasis. J. Exp. Med. 2020, 217. [CrossRef]

285. Zhen, Y.; Zhang, H. NLRP3 Inflammasome and Inflammatory Bowel Disease. Front. Immunol. 2019, 10, 276. [CrossRef] [PubMed]

286. Hu, B.; Elinav, E.; Huber, S.; Strowig, T.; Hao, L.; Hafemann, A.; Jin, C.; Wunderlich, C.; Wunderlich, T.; Eisenbarth, S.C.; et al. Microbiota-Induced Activation of Epithelial IL-6 Signaling Links Inflammasome-Driven Inflammation with Transmissible Cancer. Proc. Natl. Acad. Sci. USA 2013, 110, 9862-9867. [CrossRef] [PubMed]

287. Kelley, N.; Jeltema, D.; Duan, Y.; He, Y. The NLRP3 Inflammasome: An Overview of Mechanisms of Activation and Regulation. Int. J. Mol. Sci. 2019, 20, 3328. [CrossRef]

288. Andrade-Oliveira, V.; Foresto-Neto, O.; Watanabe, I.K.M.; Zatz, R.; Câmara, N.O.S. Inflammation in Renal Diseases: New and Old Players. Front. Pharmacol. 2019, 10, 1192. [CrossRef] [PubMed]

289. Valiño-Rivas, L.; Cuarental, L.; Nuñez, G.; Sanz, A.B.; Ortiz, A.; Sanchez-Niño, M.D. Loss of NLRP6 Expression Increases the Severity of Acute Kidney Injury. Nephrol. Dial. Transpl. 2020, 35, 587-598. [CrossRef] [PubMed]

290. Inserra, A.; Rogers, G.B.; Licinio, J.; Wong, M.-L. The Microbiota-Inflammasome Hypothesis of Major Depression. BioEssays 2018, 40, 1800027. [CrossRef]

291. Truax, A.D.; Chen, L.; Tam, J.W.; Cheng, N.; Guo, H.; Koblansky, A.A.; Chou, W.-C.; Wilson, J.E.; Brickey, W.J.; Petrucelli, A.; et al. The Inhibitory Innate Immune Sensor NLRP12 Maintains a Threshold against Obesity by Regulating Gut Microbiota Homeostasis. Cell Host Microbe 2018, 24, 364-378.e6. [CrossRef]

292. Singh, V.; Yeoh, B.S.; Walker, R.E.; Xiao, X.; Saha, P.; Golonka, R.M.; Cai, J.; Bretin, A.C.A.; Cheng, X.; Liu, Q.; et al. Microbiota Fermentation-NLRP3 Axis Shapes the Impact of Dietary Fibres on Intestinal Inflammation. Gut 2019, 68, 1801-1812. [CrossRef]

293. Hara, H.; Seregin, S.S.; Yang, D.; Fukase, K.; Chamaillard, M.; Alnemri, E.S.; Inohara, N.; Chen, G.Y.; Núñez, G. The NLRP6 Inflammasome Recognizes Lipoteichoic Acid and Regulates Gram-Positive Pathogen Infection. Cell 2018, 175, 1651-1664.e14. [CrossRef] [PubMed]

294. Venuprasad, K.; Theiss, A.L. NLRP6 in Host Defense and Intestinal Inflammation. Cell Rep. 2021, 35, 109043. [CrossRef]

295. Levy, M.; Thaiss, C.A.; Zeevi, D.; Dohnalová, L.; Zilberman-Schapira, G.; Mahdi, J.A.; David, E.; Savidor, A.; Korem, T.; Herzig, Y.; et al. Microbiota-Modulated Metabolites Shape the Intestinal Microenvironment by Regulating NLRP6 Inflammasome Signaling. Cell 2015, 163, 1428-1443. [CrossRef] 
296. Frei, R.; Ferstl, R.; Konieczna, P.; Ziegler, M.; Simon, T.; Rugeles, T.M.; Mailand, S.; Watanabe, T.; Lauener, R.; Akdis, C.A.; et al. Histamine Receptor 2 Modifies Dendritic Cell Responses to Microbial Ligands. J. Allergy Clin. Immunol. 2013, 132, 194-204. [CrossRef] [PubMed]

297. Ferstl, R.; Frei, R.; Schiavi, E.; Konieczna, P.; Barcik, W.; Ziegler, M.; Lauener, R.P.; Chassard, C.; Lacroix, C.; Akdis, C.A.; et al. Histamine Receptor 2 Is a Key Influence in Immune Responses to Intestinal Histamine-Secreting Microbes. J. Allergy Clin. Immunol. 2014, 134, 744-746. [CrossRef]

298. Angosto-Bazarra, D.; Molina-López, C.; Peñín-Franch, A.; Hurtado-Navarro, L.; Pelegrín, P. Techniques to Study Inflammasome Activation and Inhibition by Small Molecules. Molecules 2021, 26, 1704. [CrossRef]

299. Fritz, J.H.; Girardin, S.E.; Fitting, C.; Werts, C.; Mengin-Lecreulx, D.; Caroff, M.; Cavaillon, J.-M.; Philpott, D.J.; Adib-Conquy, M. Synergistic Stimulation of Human Monocytes and Dendritic Cells by Toll-like Receptor 4 and NOD1- and NOD2-Activating Agonists. Eur. J. Immunol. 2005, 35, 2459-2470. [CrossRef]

300. Tada, H.; Aiba, S.; Shibata, K.-I.; Ohteki, T.; Takada, H. Synergistic Effect of Nod1 and Nod2 Agonists with Toll-like Receptor Agonists on Human Dendritic Cells to Generate Interleukin-12 and T Helper Type 1 Cells. Infect. Immun. 2005, 73, 7967-7976. [CrossRef] [PubMed]

301. van Heel, D.A.; Ghosh, S.; Butler, M.; Hunt, K.; Foxwell, B.M.J.; Mengin-Lecreulx, D.; Playford, R.J. Synergistic Enhancement of Toll-like Receptor Responses by NOD1 Activation. Eur. J. Immunol. 2005, 35, 2471-2476. [CrossRef]

302. Schirbel, A.; Kessler, S.; Rieder, F.; West, G.; Rebert, N.; Asosingh, K.; McDonald, C.; Fiocchi, C. Pro-Angiogenic Activity of TLRs and NLRs: A Novel Link between Gut Microbiota and Intestinal Angiogenesis. Gastroenterology 2013, 144, 613-623.e9. [CrossRef] [PubMed]

303. Bäuerl, C.; Coll-Marqués, J.M.; Tarazona-González, C.; Pérez-Martínez, G. Lactobacillus Casei Extracellular Vesicles Stimulate EGFR Pathway Likely due to the Presence of Proteins P40 and P75 Bound to Their Surface. Sci. Rep. 2020, 10, 19237. [CrossRef]

304. Bäuerl, C.; Abitayeva, G.; Sosa-Carrillo, S.; Mencher-Beltrán, A.; Navarro-Lleó, N.; Coll-Marqués, J.M.; Zúñiga-Cabrera, M.; Shaikhin, S.; Pérez-Martinez, G. P40 and P75 Are Singular Functional Muramidases Present in the Lactobacillus Casei / paracasei/rhamnosus Taxon. Front. Microbiol. 2019, 10, 1420. [CrossRef]

305. Giani, A.D.; De Giani, A.; Bovio, F.; Forcella, M.; Fusi, P.; Sello, G.; Di Gennaro, P. Identification of a Bacteriocin-like Compound from Lactobacillus Plantarum with Antimicrobial Activity and Effects on Normal and Cancerogenic Human Intestinal Cells. AMB Express 2019, 9. [CrossRef]

306. Wentworth, C.C.; Jones, R.M.; Kwon, Y.M.; Nusrat, A.; Neish, A.S. Commensal-Epithelial Signaling Mediated via Formyl Peptide Receptors. Am. J. Pathol. 2010, 177, 2782-2790. [CrossRef]

307. Koczulla, R.; von Degenfeld, G.; Kupatt, C.; Krötz, F.; Zahler, S.; Gloe, T.; Issbrücker, K.; Unterberger, P.; Zaiou, M.; Lebherz, C.; et al. An Angiogenic Role for the Human Peptide Antibiotic LL-37/hCAP-18. J. Clin. Investig. 2003, 111, 1665-1672. [CrossRef]

308. Yang, D.; Chertov, O.; Bykovskaia, S.N.; Chen, Q.; Buffo, M.J.; Shogan, J.; Anderson, M.; Schröder, J.M.; Wang, J.M.; Howard, O.M.; et al. Beta-Defensins: Linking Innate and Adaptive Immunity through Dendritic and T Cell CCR6. Science 1999, 286, 525-528. [CrossRef]

309. Chambers, E.S.; Preston, T.; Frost, G.; Morrison, D.J. Role of Gut Microbiota-Generated Short-Chain Fatty Acids in Metabolic and Cardiovascular Health. Curr. Nutr. Rep. 2018, 7, 198-206. [CrossRef] [PubMed]

310. Smith, P.M.; Howitt, M.R.; Panikov, N.; Michaud, M.; Gallini, C.A.; Bohlooly-Y, M.; Glickman, J.N.; Garrett, W.S. The Microbial Metabolites, Short-Chain Fatty Acids, Regulate Colonic Treg Cell Homeostasis. Science 2013, 341, 569-573. [CrossRef]

311. Silva, Y.P.; Bernardi, A.; Frozza, R.L. The Role of Short-Chain Fatty Acids From Gut Microbiota in Gut-Brain Communication. Front. Endocrinol. 2020, 11, 25. [CrossRef] [PubMed]

312. Li, M.; van Esch, B.C.A.M.; Wagenaar, G.T.M.; Garssen, J.; Folkerts, G.; Henricks, P.A.J. Pro- and Anti-Inflammatory Effects of Short Chain Fatty Acids on Immune and Endothelial Cells. Eur. J. Pharmacol. 2018, 831, 52-59. [CrossRef]

313. Hoving, J.C.; Wilson, G.J.; Brown, G.D. Signalling C-Type Lectin Receptors, Microbial Recognition and Immunity. Cell. Microbiol. 2014, 16, 185-194. [CrossRef] [PubMed]

314. Robinson, M.J.; Sancho, D.; Slack, E.C.; LeibundGut-Landmann, S.; Reis e Sousa, C. Myeloid C-Type Lectins in Innate Immunity. Nat. Immunol. 2006, 7, 1258-1265. [CrossRef]

315. Dambuza, I.M.; Brown, G.D. C-Type Lectins in Immunity: Recent Developments. Curr. Opin. Immunol. 2015, 32, 21-27. [CrossRef]

316. Mnich, M.E.; van Dalen, R.; van Sorge, N.M. C-Type Lectin Receptors in Host Defense Against Bacterial Pathogens. Front. Cell. Infect. Microbiol. 2020, 10, 309. [CrossRef] [PubMed]

317. Kerrigan, A.M.; Brown, G.D. C-Type Lectins and Phagocytosis. Immunobiology 2009, 214, 562-575. [CrossRef]

318. Chiffoleau, E. C-Type Lectin-Like Receptors As Emerging Orchestrators of Sterile Inflammation Represent Potential Therapeutic Targets. Front. Immunol. 2018, 9, 227. [CrossRef] [PubMed]

319. Geijtenbeek, T.B.H.; Torensma, R.; van Vliet, S.J.; van Duijnhoven, G.C.F.; Adema, G.J.; van Kooyk, Y.; Figdor, C.G. Identification of DC-SIGN, a Novel Dendritic Cell-Specific ICAM-3 Receptor That Supports Primary Immune Responses. Cell 2000, 100, 575-585. [CrossRef]

320. Lai, W.K.; Sun, P.J.; Zhang, J.; Jennings, A.; Lalor, P.F.; Hubscher, S.; McKeating, J.A.; Adams, D.H. Expression of DC-SIGN and DC-SIGNR on Human Sinusoidal Endothelium: A Role for Capturing Hepatitis C Virus Particles. Am. J. Pathol. 2006, 169, 200-208. [CrossRef] [PubMed] 
321. Tailleux, L.; Pham-Thi, N.; Bergeron-Lafaurie, A.; Herrmann, J.-L.; Charles, P.; Schwartz, O.; Scheinmann, P.; Lagrange, P.H.; de Blic, J.; Tazi, A.; et al. DC-SIGN Induction in Alveolar Macrophages Defines Privileged Target Host Cells for Mycobacteria in Patients with Tuberculosis. PLoS Med. 2005, 2, e381. [CrossRef] [PubMed]

322. Svajger, U.; Anderluh, M.; Jeras, M.; Obermajer, N. C-Type Lectin DC-SIGN: An Adhesion, Signalling and Antigen-Uptake Molecule That Guides Dendritic Cells in Immunity. Cell. Signal. 2010, 22, 1397-1405. [CrossRef]

323. Castro-Bravo, N.; Wells, J.M.; Margolles, A.; Ruas-Madiedo, P. Interactions of Surface Exopolysaccharides From Bifidobacterium and Lactobacillus Within the Intestinal Environment. Front. Microbiol. 2018, 9, 2426. [CrossRef]

324. Castro-Bravo, N.; Margolles, A.; Wells, J.M.; Ruas-Madiedo, P. Exopolysaccharides Synthesized by Bifidobacterium Animalis Subsp. Lactis Interact with TLR4 in Intestinal Epithelial Cells. Anaerobe 2019, 56, 98-101. [CrossRef] [PubMed]

325. López, P.; Monteserín, D.C.; Gueimonde, M.; de los Reyes-Gavilán, C.G.; Margolles, A.; Suárez, A.; Ruas-Madiedo, P. Exopolysaccharide-Producing Bifidobacterium Strains Elicit Different in Vitro Responses upon Interaction with Human Cells. Food Res. Int. 2012, 46, 99-107. [CrossRef]

326. Górska, S.; Sandstrőm, C.; Wojas-Turek, J.; Rossowska, J.; Pajtasz-Piasecka, E.; Brzozowska, E.; Gamian, A. Structural and Immunomodulatory Differences among Lactobacilli Exopolysaccharides Isolated from Intestines of Mice with Experimentally Induced Inflammatory Bowel Disease. Sci. Rep. 2016, 6, 1-16. [CrossRef] [PubMed]

327. Bleau, C.; Monges, A.; Rashidan, K.; Laverdure, J.-P.; Lacroix, M.; Van Calsteren, M.-R.; Millette, M.; Savard, R.; Lamontagne, L. Intermediate Chains of Exopolysaccharides from Lactobacillus Rhamnosus RW-9595M Increase IL-10 Production by Macrophages. J. Appl. Microbiol. 2010, 108, 666-675. [CrossRef] [PubMed]

328. Mazmanian, S.K.; Round, J.L.; Kasper, D.L. A Microbial Symbiosis Factor Prevents Intestinal Inflammatory Disease. Nature 2008, 453, 620-625. [CrossRef] [PubMed]

329. Laiño, J.; Villena, J.; Kanmani, P.; Kitazawa, H. Immunoregulatory Effects Triggered by Lactic Acid Bacteria Exopolysaccharides: New Insights into Molecular Interactions with Host Cells. Microorganisms 2016, 4, 27. [CrossRef] [PubMed]

330. Konieczna, P.; Schiavi, E.; Ziegler, M.; Groeger, D.; Healy, S.; Grant, R.; O'Mahony, L. Human Dendritic Cell DC-SIGN and TLR-2 Mediate Complementary Immune Regulatory Activities in Response to Lactobacillus Rhamnosus JB-1. PLoS ONE 2015, 10, e0120261. [CrossRef]

331. Tytgat, H.L.P.; van Teijlingen, N.H.; Sullan, R.M.A.; Douillard, F.P.; Rasinkangas, P.; Messing, M.; Reunanen, J.; Satokari, R.; Vanderleyden, J.; Dufrêne, Y.F.; et al. Probiotic Gut Microbiota Isolate Interacts with Dendritic Cells via Glycosylated Heterotrimeric Pili. PLoS ONE 2016, 11, e0151824. [CrossRef]

332. Fagan, R.P.; Fairweather, N.F. Biogenesis and Functions of Bacterial S-Layers. Nat. Rev. Microbiol. 2014, 12, 211-222. [CrossRef]

333. Sleytr, U.B.; Schuster, B.; Egelseer, E.-M.; Pum, D. S-Layers: Principles and Applications. FEMS Microbiol. Rev. $2014,38,823-864$. [CrossRef]

334. Konstantinov, S.R.; Smidt, H.; de Vos, W.M.; Bruijns, S.C.M.; Singh, S.K.; Valence, F.; Molle, D.; Lortal, S.; Altermann, E.; Klaenhammer, T.R.; et al. S Layer Protein A of Lactobacillus Acidophilus NCFM Regulates Immature Dendritic Cell and T Cell Functions. Proc. Natl. Acad. Sci. USA 2008, 105, 19474-19479. [CrossRef] [PubMed]

335. Chapot-Chartier, M.-P.; Kulakauskas, S. Cell Wall Structure and Function in Lactic Acid Bacteria. Microb. Cell Factories 2014, 13, S9. [CrossRef] [PubMed]

336. Costerton, J.W.; Stewart, P.S.; Greenberg, E.P. Bacterial Biofilms: A Common Cause of Persistent Infections. Science 1999, 284, 1318-1322. [CrossRef] [PubMed]

337. Hold, G.L.; Garrett, W.S. Gut Microbiota. Microbiota Organization-A Key to Understanding CRC Development. Nat. Rev. Gastroenterol. Hepatol. 2015, 12, 128-129. [CrossRef] [PubMed]

338. Puccetti, M.; Xiroudaki, S.; Ricci, M.; Giovagnoli, S. Postbiotic-Enabled Targeting of the Host-Microbiota-Pathogen Interface: Hints of Antibiotic Decline? Pharmaceutics 2020, 12, 624. [CrossRef] 